\title{
RESEARCH
}

Open Access

\section{Impact of human disturbances on soil cyanobacteria diversity and distribution in suburban arid area of Marrakesh, Morocco}

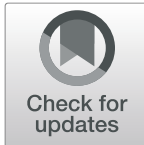

\author{
Z. Hakkoum ${ }^{1}$, F. Minaoui ${ }^{1}$, M. Douma ${ }^{1,2}$, K. Mouhri $^{1}$ and M. Loudiki ${ }^{{ }^{*}}$ (D)
}

\begin{abstract}
Background: Cyanobacteria are among the first photoautotrophic component of soil microorganism communities which play a key ecological role in nutrient cycles and soil productivity. However, the sustainability of these soil biodiversity ecosystem services is increasingly compromised, especially in urban and peri-urban areas where soils are heavily exploited and used for a wide range of human activities. The aim of this study is to assess the impact of different types of human disturbances on cyanobacteria diversity and distribution in suburban soils of Marrakesh. Soil and cyanobacteria sampling were carried out during two campaigns at six sites located along an anthropogenic gradient from the least urbanized suburbs of Marrakesh to the highly anthropized suburban area. In the laboratory, soil physicochemical characteristics were measured. The morphological identification of cyanobacteria species was based both on microscopic observation and on soil cultures in solid and liquid Z8 media.

Results: The results showed a total of 25 cyanobacteria taxa belonging to ten genera, four families, and two orders (Oscillatoriales 88\% and Chroococcales 12\% of taxa). Among the taxa identified, seven strains were isolated in soil culture in nutrient media and purified in monoalgal culture. The highest cyanobacterial diversity was recorded in irrigated soil with treated wastewater compared to the non-cultivated control soil. In Principal Component and Cluster Analysis, suburban soils were subdivided into three groups depending on the chemical properties and cyanobacteria composition. Cyanobacteria diversity was significantly associated with the soil moisture, total organic carbon (TOC), $\mathrm{PO}_{4}-\mathrm{P}, \mathrm{NO}_{3}-\mathrm{N}$, and $\mathrm{NH}_{4}-\mathrm{N}$ contents.

Conclusions: While diversity and microalgal biomass were significantly lower in the soils affected by municipal and mining solid wastes, the input of organic matter and nutrients from treated wastewater appears to be beneficial for the increasing of the biodiversity of soil cyanobacteria. This survey provides a first inventory of the soil cyanobacterial communities and shows their spatial variability and high sensitivity to the land-use practices and anthropogenic disturbances on urban soil in Moroccan drylands.
\end{abstract}

Keywords: Cyanobacteria, Peri-urban soils, Pollution, Anthropogenic effects, Moroccan drylands

\footnotetext{
*Correspondence: loudiki@uca.ac.ma

'Laboratory of Water, Biodiversity and Climate Change; Phycology,

Biotechnology and Environmental Toxicology Research Unit, Faculty of

Sciences Semlalia Marrakesh, Cadi Ayyad University, Av. Prince My Abdellah,

P.O. Box 2390, 40000 Marrakesh, Morocco

Full list of author information is available at the end of the article
}

\section{Springer Open}

(c) The Author(s). 2021 Open Access This article is licensed under a Creative Commons Attribution 4.0 International License, which permits use, sharing, adaptation, distribution and reproduction in any medium or format, as long as you give appropriate credit to the original author(s) and the source, provide a link to the Creative Commons licence, and indicate if changes were made. The images or other third party material in this article are included in the article's Creative Commons licence, unless indicated otherwise in a credit line to the material. If material is not included in the article's Creative Commons licence and your intended use is not permitted by statutory regulation or exceeds the permitted use, you will need to obtain permission directly from the copyright holder. To view a copy of this licence, visit http://creativecommons.org/licenses/by/4.0/. 


\section{Introduction}

Cyanobacteria are the oldest photoautotrophic component of microbiota that include archaea, bacteria, microalgae, microfungi, lichens, and protozoa ( Rivera-Aguilar et al. 2006; Maestre et al. 2011). They are a diverse group of prokaryotes found in a wide array of aquatic and terrestrial habitats and are well adapted to hostile environments like extremely arid and dryland areas (Douma 2010). Thanks to their numerous adaptations, they can colonize unstable substrates and their presence can also improve the environmental role and functions of the soil biocrust through carbon sequestration and nitrogen fixation (Büdel et al. 2016). They are pioneers on many nutrient-poor and abiotically stressful substrates, creating stable organomineral layers on which other species can subsequently recruit and grow (Rossi and De Philippis 2015). Cyanobacteria are well known for their agronomic importance, acting as one of the major determinants of soil fertility by adding organic matter, nitrogen and phosphorus (Whitton and Potts 2007; Singh et al. 2014; Rossi et al. 2017), reducing the erosion of soil and thus favoring the settlement of vascular plants (Lin et al. 2013). They may also contribute to the suppression of phytopathogens (Prasanna et al. 2013) and produce substances (phytohormones, carbonic acids, polysaccharides) that promote plant growth (Rodríguez et al. 2006; Karthikeyan et al. 2007; Shariatmadari et al. 2013) and improve soil aggregation and structural stability (Song et al. 2005). Moreover, cyanobacteria are best known for their adaptability to survive in polluted and heavily polluted environments and their capacity to degrade organic waste, various agrochemicals (pesticides, herbicides) and remove heavy metals and other pollutants (Vijayakumar 2012; Subashchandrabose et al. 2013; Singh et al. 2014).

Although several recent researches have shown the ecological functions and great biotechnological potential of cyanobacteria as bio-resource in agriculture, soil ecosystem remediation, and environmental sustainability (Singh et al. 2016; Bag et al. 2019; Rocha et al. 2020), the ecosystem services of cyanobacterial soil diversity are threatened by urban, agricultural and industrial land uses. Indeed, the advancing urbanization and the increase of domestic and agro-industrial effluents and wastes have caused the deterioration of soil microbial communities, including cyanobacteria (Sharma 2015). The agricultural activities are places of intensive anthropogenic activity, including tillage and the application of chemical fertilizers, pesticides, and herbicides. Such human activities affect the physicochemical properties of soils and thus could reduce the diversity of soil microalgae, including cyanobacteria (Mostafa and Helling 2002). Furthermore, mining activities generate a large amount of toxic waste (heavy metals) that is very unstable in the soil. They are a major source of soil ecosystem disturbance and cause considerable harm to vegetation and soil microorganisms (El Alaoui et al. 2019).

Soil is a complex environment characterized by a wide variety of microorganisms, chemical compounds, and complex physical structure. It not only ensures terrestrial biodiversity, but also provides habitat for a large number of organisms (Bardgett et al. 2005; Briones 2014). Urban soils and their biodiversity provide a variety of ecosystem services, including nutrient cycling, depollution, fertility, and carbon storage (Guilland et al. 2018). However, these urban soil biodiversity functions are threatened by urbanization, compaction, and pollution which cause accumulation of various contaminants, chemical compounds and heavy metals, changes in humus content, organic carbon, and pH (Carrino-Kyker et al. 2011; Maltsev et al. 2017; Li et al. 2017). Urbanization processes in natural landscapes have caused some changes in the biological factor of soil formation and the creation of artificial ecological systems (Rai et al. 2018; Wang et al. 2020). Urbanization also results in the creation of specific biotopes with a species composition characteristic of living organisms (Caruso et al. 2017; Joimel et al. 2017). This soil habitats alteration is drastic and is increasing at an alarming rate, and has emerged as a major threat to the soil microbial biodiversity (McKinney 2006). Although the research on soil biodiversity has grown exponentially over the last two decades, work has been concentrated on natural environments and few investigations have been carried out on urban soils (Joimel et al. 2017; Guilland et al. 2018; Rutgers et al. 2019). More recently, the investigation of microbial biodiversity in urban ecosystems has gained interest as an important feature of ecological investigations. Prokaryotic microalgae are an indispensable part of soil biodiversity and urban ecosystems, performing an important regulatory function and play a key role as primary producers, in self-purification processes and support the ecological stability (Shekhovtseva 2014; Maltsev et al. 2017). Other researchers suggest that their high sensitivity to environmental stressors and their omnipresence and short generation time also highlight their potential as bioindicators of global change (Kannan et al. 2012; Muñoz-Martín et al. 2019). Indeed, cyanobacteria and eukaryotic microalgae (notably diatoms) have been used as bioindicators of soil health in ecological monitoring (Maltsev et al. 2017; Barragán et al. 2017; Foets et al. 2021).

Reports on terrestrial algal communities including cyanobacteria in urban habitats have gradually emerged in the last two decades (Rindi and Guiry 2019; Dorokhova et al. 2015; Maltsev et al. 2017; Rai et al. 2018). Most of these studies were carried out in European, Asian, the USA, and South American cities while few works have been published in other continents such Africa (Rindi 2007; Guilland et al. 2018). In the 
Northern part of Africa with larger arid and hyper-arid landscapes, little is known about the soil cyanobacteria communities that are still underexplored and where their ecology remains little known. In Morocco, where urbanization is growing in extent and intensity, no studies have been carried out on the abundance and diversity of urban soil cyanobacteria and the human impact assessment. The aim of this study is to investigate the cyanobacterial diversity of peri-urban soils and evaluate the impact of the human disturbances on their distribution along a rural-urban land use gradient in Marrakesh arid area. We investigated the effect of different types of disturbances and land use practices (non-cultivated rural soil, non-cultivated soil from the palm grove of Marrakech, agricultural soil irrigated by groundwater, agricultural soil irrigated by waste water, soil from public dumps, soil contaminated by mine wastes) in order to (a) assess their impact on soil physicochemical properties and the composition and diversity of urban soil cyanobacteria and (b) understand their effect on the ecology of soil cyanobacterial communities and determine the factors affecting the distribution and variability of these microprokaryotes in response to the land use practices.

\section{Materials and methods}

\section{Study area}

The study was conducted in Marrakesh peri-urban area (southwestern of Morocco, Fig. 1) known for its arid climate and low rainfall during the wet season (150-300 $\mathrm{mm}$ ) (Stour and Agoumi 2008). Temperatures show large ranges of daily and seasonal variations. In winter, the minimum temperature can drop below $0^{\circ} \mathrm{C}$ with an average of $5^{\circ} \mathrm{C}$. In summer, maximum temperatures of 48 to $50^{\circ} \mathrm{C}$ can be observed (El Khalil et al. 2013). The area of Marrakesh is located on recent quaternary formations (alluvium, alluvial loam, and red surface loam) and on recent and partially fixed sand dumps (Hibti 2001). The natural vegetation cover is composed by the jujube steppe, pistachio, date palm, and olive trees (El Faïz 2002).

In recent years, the Marrakesh city (with almost 1 million inhabitants) has undergone accelerated expansion and urbanization. The development, in the peripheral area, of different human activities and land use practices (e.g., agriculture, industry, mines and quarries, tourist attractions...) and the installation of sanitation infrastructure (wastewater treatment plant, landfill site) generate strong pressures with a potential impact on suburban soils. The study area was selected in the northern periurban zone of the city (Fig. 1) characterized by different types of disturbances. This area was chosen based on the existence of an increasing urbanization gradient from east to west in order to compare the cyanobacterial diversity between rural (least urbanized) and urban anthropized soils.

\section{Sampling sites and soil sampling}

Six sampling sites were selected along an anthropogenic gradient according to the current human activity, land use, and cultivation practices. Soil samples were collected in five potential disturbed sites and one least urbanized rural reference site (Fig. 1). The use of one single site as a control area is justified by the homogeneous geochemical composition of the soil in Marrakech area allowing the separation of anthropogenic impacts

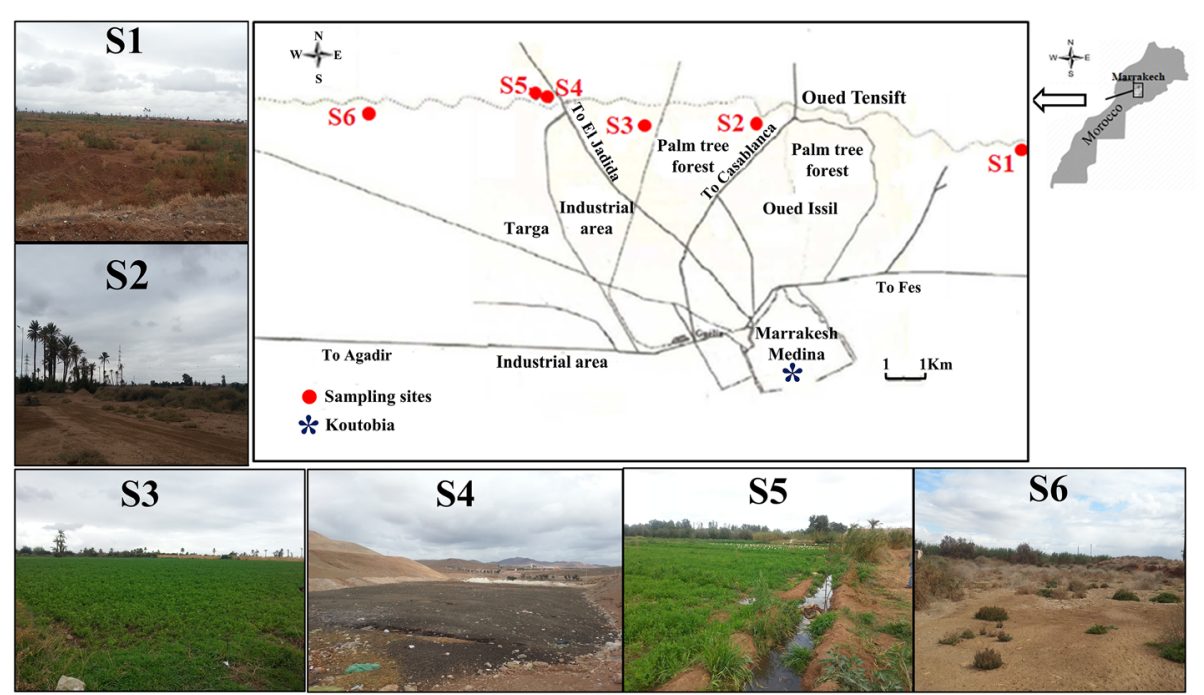

Fig. 1 Location of sampling sites in Marrakech peri-urban area. S1: reference Site; S2: non-cultivated land —construction waste area; S3: Cultivated land-groundwater; S4: non-cultivated land_-former dump; S5: cultivated land_treated wastewater; S6: non-cultivated land mine wastes (the map of Marrakesh city is carried out by El Khalil et al. (2013) 
Table 1 Description of sampling sites

\begin{tabular}{|c|c|c|c|}
\hline Sampling sites & Coordinates & $\begin{array}{l}\text { Altitude } \\
(\mathrm{m})\end{array}$ & Type of disturbance and land uses \\
\hline $\begin{array}{l}\text { S1: } \\
\text { Reference site }\end{array}$ & $\begin{array}{l}N: 31^{\circ} 25.226^{\prime} \\
W: 007^{\circ} \\
50.240^{\prime}\end{array}$ & 436 & $\begin{array}{l}\text { Reference site, located at } 20 \mathrm{~km} \text { east of Marrakesh, uncultivated land, } \\
\text { jujube steppe soil. Rural area without significant human activities. }\end{array}$ \\
\hline $\begin{array}{l}\text { S2: } \\
\text { Non-cultivated land_-construction waste area }\end{array}$ & $\begin{array}{l}N: 31^{\circ} 41.284^{\prime} \\
W: 007^{\circ} \\
59.823^{\prime}\end{array}$ & 397 & $\begin{array}{l}\text { Non-cultivated land, site located on the palm grove of Marrakech. } \\
\text { Soil slightly disturbed by construction waste. }\end{array}$ \\
\hline S3: Cultivated land_-groundwater & $\begin{array}{l}N: 31^{\circ} 41.181^{\prime} \\
W: 008^{\circ} \\
01.924^{\prime}\end{array}$ & 402 & $\begin{array}{l}\text { Cultivated land, Food and fodder crop fields. Soil fertilized and } \\
\text { irrigated by groundwater. }\end{array}$ \\
\hline $\begin{array}{l}\text { S4: } \\
\text { Non-cultivated land-former dump of } \\
\text { Marrakesh }\end{array}$ & $\begin{array}{l}N: 31^{\circ} 42, .170^{\prime} \\
W: 008^{\circ} \\
03.921^{\prime}\end{array}$ & 405 & $\begin{array}{l}\text { Non-cultivated land, site located near the former public dumps } \\
\text { of Marrakech. Polluted soil by the discharges of municipal solid waste. }\end{array}$ \\
\hline $\begin{array}{l}\text { S5: } \\
\text { Cultivated land_-treated wastewater }\end{array}$ & $\begin{array}{l}N: 31^{\circ} 42.373^{\prime} \\
W: 008^{\circ} \\
04.312^{\prime}\end{array}$ & 385 & $\begin{array}{l}\text { Cultivated land, Cereal and alfalfa fields and crops. Irrigated soil by } \\
\text { treated wastewater from the Marrakesh treatment plant. }\end{array}$ \\
\hline $\begin{array}{l}\text { S6: } \\
\text { Non-cultivated } \\
\text { land-mine wastes }\end{array}$ & $\begin{array}{l}N: 31^{\circ} 42.906^{\prime} \\
W: 008^{\circ} \\
08.091^{\prime}\end{array}$ & 372 & $\begin{array}{l}\text { Non-cultivated land, site located at } 13 \mathrm{~km} \text { northwest of Marrakesh in } \\
\text { the vicinity of the Draa Lasfar mine } \\
\text { (production of copper, cobalt, zinc, and lead). Soil contaminated by } \\
\text { solid mine wastes. }\end{array}$ \\
\hline
\end{tabular}

from intrinsic variables. According to El Khalil et al. (2013), the peri-urban and urban soils of Marrakech present geochemical compositions that are generally similar for many elements. Table 1 provides a description of the sampling sites, information on types of human disturbance, land use, and potential polluting agents.

Eighteen soil samples $(6$ sites $\times 3$ replicates per site) were collected at the six sites on February 15 (cold and humid period) and May 5 (warmer and drier period), 2016. In each sampling site, an area of $500-1000 \mathrm{~m}^{2}$ was investigated to select three representative soil sampling points, showing a range of biocrust colonization states (Belnap et al. 2008). At each sampling point, one composite soil sample was taken from the surface layer after removal of moss, lichen, or vascular plants if any, as previously described by Garcia-Pichel et al. (2016). Each composite sample consists of six small sub-samples of $10 \mathrm{~cm}^{2}$ in area and $0-5-\mathrm{cm}$ deep, taken randomly with a sterile spatula. Samples were collected in clean polyethylene bags and maintained at $4{ }^{\circ} \mathrm{C}$ until further analysis (Řeháková et al. 2011).

\section{Soil physicochemical property measurements}

In the laboratory, the soil samples were air-dried at room temperature and sieved $(<2 \mathrm{~mm})$ for physicochemical analysis (El Khalil et al. 2013). The soil analysis was performed on the $<2 \mathrm{~mm}$ size fraction according to NF ISO 10260 (1992). A conductivity meter (Cond 1970i WTW GmbH, Weilheim, Germany) was used to measure the electrical conductivity. The $\mathrm{pH}$ was determined using a $\mathrm{pH}$ meter ( $\mathrm{pH}$ 1970i WTW GmbH, Weilheim, Germany). Anne's method (Aubert 1978) was used to estimate total organic carbon (TOC). This method is used to assess the organic matter content of soil samples. Available phosphorus was quantified by the Olsen method (Olsen et al. 1954). The ammonium nitrogen $\left(\mathrm{NH}_{4}-\mathrm{N}\right)$ and nitrate nitrogen $\left(\mathrm{NO}_{3}-\mathrm{N}\right)$ contents were measured according to AFNOR (1975) and Devarda's alloy method (Liao 1981), respectively. The soil moisture was measured gravimetrically according to the standard method (AFNOR 2000). The soil samples were ovendried at $105^{\circ} \mathrm{C}$ for $48 \mathrm{~h}$ based on the oven drying method. The chlorophyll a (chl-a) content of the soil was determined by extraction with boiling ethanol (NF ISO 10260, 1992).

\section{Taxonomic identification of cyanobacteria}

Morphological identification of cyanobacterial taxa was performed using field samples and soil cultures on enriched medium (Mansour and Shaaban 2010). A suspension of each soil sample was obtained by dissolving 1 $\mathrm{g}$ of soil diluted $10 \mathrm{ml}$ fold in sterilized distilled water. A few drops of this suspension were instantly observed under a research optical microscope (Motic BA210, China, $\times 400$ and $\times 1000$ magnification) to do a preliminary identification of the cyanobacterial taxa. They were then identified using recent monographs on cyanobacteria. (Anagnostidis and Komarek 1990; Komárek and Anagnostidis 1998; Komárek and Anagnostidis 2005; Komárek 2013).

\section{Strain isolation and culture conditions of cyanobacteria}

In order to identify cyanobacterial taxa that not be observed in field material, enrichment cultures in solid and liquid media were carried out as described by Hakkoum 
et al. (2020). After sieving and grinding soil samples, a series of 5 dilutions ranged from $10^{-1}$ to $10^{-5}$ were prepared. Under aseptic conditions, $1 \mathrm{ml}$ of the soil suspension of each dilution was inoculated in triplicate on solid (1.5\% agar) and then on liquid media. Z8 medium, originally described by Kotai (1972), was used for the cyanobacteria strain isolation. Although no single medium will work for all species, the use of Z8 medium has been widely used for the isolation and culture of several cyanobacteria. Its selectivity for cyanobacteria isolates can be improved by modified nutrient (especially nitrogen) content and low-light incubation which limit the growth of most other eukaryotic algae. Morover, the omission of copper from trace element solution may be the key to its ability to support the growth of cyanobacteria (Skulberg 1983). The cultures were maintained under controlled conditions (temperature $26{ }^{\circ} \mathrm{C} \pm 1$, light intensity $60 \mu \mathrm{mol} / \mathrm{m}^{-2} / \mathrm{s}$, light-dark cycle of $15 / 9$ $\mathrm{h}$ with continuous aeration) for 8 to 12 days. After the growth of the cyanobacteria, a series of successive transplants of the isolated strains on a new medium was carried out to obtain a purified monoalgal culture. The monoalgal strains were utilized for in-depth morphological identification of the species under light microscopy (Motic BA210, China) using the analysis of the imaging software (Motic images+ 2.0).

\section{Data analysis}

The analysis of all soil parameters was done in triplicate per sampling site. The results are given in mean \pm standard error (SE). Two-way Analysis of Variance (ANOVA) was performed to assess the significant effects of main factors (type of disturbance and sampling time) and their interaction. Significant differences among these two factors were calculated at 5\%. When the interaction between factors was significant according to the ANOVA analysis, post hoc comparisons with Tukey's HSD test were used to find differences between groups. The ANOVA analysis was carried out using SPSS version 22.0 statistical software (IBM Corp. 2013).

Multivariate analysis was made to identify correlations between different groups of cyanobacteria and soil properties using principal component analysis (PCA). In the data matrix, the individuals are the sampling sites (6); the variables are the cyanobacteria taxa (25) and the physicochemical parameters (7). The PCA ordinations were constructed from a distance matrix of environmental variables. Next, a cluster analysis was carried out to establish a soil typology and evaluate the degree of similarity of the study sites. The analysis was performed using XLSTAT 2016 version 18.02.01.27444; Addinsoft, France.

\section{Results}

\section{Soil physicochemical parameters}

The two-way ANOVA revealed highly significant $(p<0.01)$ effect of site (type of disturbance) and sampling time on soil physicochemical parameters except $\mathrm{pH}$ and $\mathrm{NH}_{4}-\mathrm{N}$ with non-significant effect of sampling time (Table 2). The spatial variability of $\mathrm{pH}$ and $\mathrm{NH}_{4}-\mathrm{N}$ exceeded temporal variability. All measured parameters were also significantly influenced by the interaction of the two factors (total effect). The $\mathrm{pH}$ values were significantly $(p<0.05)$ decreased with increasing urbanization gradient. The soil $\mathrm{pH}$ values were significantly $(p<0.05)$ more neutral at the strongly disturbed sites as compared with the reference site. Electrical conductivity showed a significant increase $(p<0.05)$ with increasing urbanization gradient. The highest values were recorded in the strongly anthropized soils, with 3175 and $2250 \mu \mathrm{S} / \mathrm{cm}$ in the former dump and in vicinity of the Draa Lasfar mine site, respectively., while the reference site (S1) showed the lowest value $(179.8 \mu \mathrm{S} / \mathrm{cm})$. The soil moisture of the irrigated soils (S3 and S5) was significantly higher than the other types of land uses. In addition, at all sites, soil moisture values showed a remarkable significant increase $(p<0.05)$ during the February campaign (up to $26.03 \%$ in S3), whereas it decreased during the May campaign (up to $3.6 \%$ in S1), except in S6. Agricultural irrigated (S3, S5) and landfill soils (S4) had a significant $(p<0.05)$ higher concentrations of total organic carbon, ammonium and nitrate nitrogen, and available phosphorus, while the lowest contents was observed at the non-cultivated control site (S1) and the mine site (S6).

\section{Chlorophyll a and soil algal biomass}

The soil algal biomass, as assessed by chl-a content, was significantly different $(p<0.05)$ between soils ranged from $0.36 \mu \mathrm{g} / . \mathrm{g}$ at the mining soil to $39.36 \mu \mathrm{g} / \mathrm{g}^{-1}$ at irrigated soil with treated wastewater (Fig. 2). The chl-a content was significantly $(p<0.05)$ higher at the irrigated soils (S3 and S5) and lower at the landfill (S4) and mining soils (S6) compared with the reference site. The two-way ANOVA showed a significant effect $(p<0.05)$ of the sampling time on the chl-a of the undisturbed soils (S1 and S2) (Fig. 2). However, at human disturbed soils (S3, S4, S5, and S6), the spatial variability (disturbance effect) of chl-a exceeds the seasonal variability.

\section{Cyanobacterial diversity: morphological identification and strain isolation}

Using a culture-based approach, a total of 25 cyanobacteria taxa were identified in the soil samples (Table 3), belonging to 2 orders, 4 families, and 10 genera (Fig. 3b, c). The Oscillatoriales are the most diverse order with $88 \%$ of all taxa, followed by the Chroococcales (12\%) (Table 4). The species richness was significantly different $(p<0.05)$ between soils (Fig. 3a). The highest species number was observed in agricultural soils irrigated either 
Table 2 Physicochemical properties of sampled soils

\begin{tabular}{|c|c|c|c|c|c|c|c|c|}
\hline \multicolumn{2}{|c|}{ Parameter } & \multirow{2}{*}{$\begin{array}{l}\mathbf{p H} \\
9.04^{\mathbf{a}_{1}} \pm 0.01\end{array}$} & \multirow{2}{*}{$\begin{array}{l}\text { EC } \\
180.3^{\mathbf{f}} \pm 1.80\end{array}$} & \multirow{2}{*}{$\begin{array}{l}\mathbf{H} \\
6.55^{\mathbf{f}} \pm 0.05\end{array}$} & \multirow{2}{*}{$\begin{array}{l}\text { TOC } \\
0.63^{\mathbf{f}_{ \pm}} \pm 0.03\end{array}$} & \multirow{2}{*}{$\frac{\mathbf{P O}_{\mathbf{4}} \mathbf{- P}}{0.17^{\mathbf{f}} \pm 0.00}$} & \multirow{2}{*}{$\frac{\mathrm{NH}_{\mathbf{4}} \mathbf{- N}}{0.02^{\mathbf{d}_{1}} \pm 0.00}$} & \multirow{2}{*}{$\frac{\mathrm{NO}_{3}-\mathbf{N}}{0.07^{\mathbf{b}} \pm 0.00}$} \\
\hline $\mathrm{S1}$ & $\mathrm{F}$ & & & & & & & \\
\hline & M & $8.03^{\mathbf{a}} \pm 0.00$ & $179.8^{\mathbf{f}} \pm 1.80$ & $3.90^{\mathbf{f}} \pm 0.01$ & $0.43^{\mathbf{f}} \pm 0.03$ & $0.16^{\mathbf{f}} \pm 0.01$ & $0.01^{\mathrm{d}} \pm 0.00$ & $0.07^{\mathbf{b}} \pm 0.00$ \\
\hline \multirow[t]{2}{*}{$\mathrm{S} 2$} & F & $7.16^{\mathbf{d}_{ \pm 0.00}}$ & $517.5^{\mathbf{e}_{ \pm}} 52.50$ & $15.47^{c} \pm 0.05$ & $3.61^{c} \pm 1.85$ & $0.96^{d_{ \pm}} \pm 0.12$ & $0.02^{\mathrm{d}} \pm 0.00$ & $0.09^{\mathbf{b}} \pm 0.01$ \\
\hline & M & $7.64^{\mathbf{b}} \pm 0.00$ & $488.45^{\mathbf{e}} \pm 8.45$ & $12.84^{\mathbf{c}} \pm 0.02$ & $2.22^{d} \pm 1.11$ & $0.82^{\mathrm{d}} \pm 0.12$ & $0.02^{d} \pm 0.00$ & $0.08^{\mathbf{b}} \pm 0.00$ \\
\hline \multirow[t]{2}{*}{ S3 } & $\mathrm{F}$ & $7.29^{\mathbf{c}} \pm 0.02$ & $698.5^{d^{d}} \pm 2.50$ & $26.04^{\mathbf{a}_{ \pm}} \pm 0.31$ & $5.26^{\mathbf{b}_{ \pm}} \pm 0.00$ & $1.03^{c} \pm 0.06$ & $0.10^{c} \pm 0.00$ & $0.13^{a_{ \pm}} \pm 0.00$ \\
\hline & M & $7.65^{\mathbf{b}_{ \pm}} 0.07$ & $667.5^{d} \pm 2.50$ & $19.70^{\mathbf{a}} \pm 0.08$ & $4.44^{\mathbf{c}} \pm 1.11$ & $1.02^{c} \pm 0.16$ & $0.11^{c} \pm 0.00$ & $0.10^{\mathbf{a}_{ \pm}} \pm 0.00$ \\
\hline \multirow[t]{2}{*}{ S4 } & $\mathrm{F}$ & $7.33^{c} \pm 0.02$ & $3175^{\mathbf{a}} \pm 5.00$ & $8.07^{d} \pm 0.02$ & $7.40^{\mathbf{a}} \pm 1.05$ & $2.03^{a} \pm 0.10$ & $0.14^{\mathbf{a}} \pm 0.00$ & $0.17^{\mathbf{a}_{ \pm}} \pm .01$ \\
\hline & M & $7.77^{\mathbf{b}} \pm 0.00$ & $3127.5^{\mathbf{a}_{ \pm}} 2.50$ & $7.95^{\mathbf{e}_{ \pm}} \pm 0.03$ & $6.66^{\mathbf{a}} \pm 1.33$ & $1.58^{a_{ \pm}} 0.01$ & $0.16^{\mathbf{a}} \pm 0$ & $0.15^{\mathbf{a}_{ \pm}} \pm .01$ \\
\hline \multirow[t]{2}{*}{ S5 } & $\mathrm{F}$ & $7.20^{d} \pm 0.20$ & $856^{\mathbf{c}} \pm 4.00$ & $18.58^{\mathbf{b}} \pm 0.17$ & $6.66^{\mathbf{a}} \pm 0.00$ & $1.28^{\mathbf{b}} \pm 0.15$ & $0.12^{\mathbf{b}} \pm 0.00$ & $0.15^{\mathbf{a}_{ \pm}} \pm 0.01$ \\
\hline & M & $7.10^{c} \pm 0.30$ & $910^{c} \pm 20.00$ & $16.90^{\mathbf{b}} \pm 0.01$ & $5.55^{\mathbf{b}} \pm 1.11$ & $1.19^{\mathbf{b}} \pm 0.01$ & $0.11^{b} \pm 0.00$ & $0.13^{\mathbf{a}_{ \pm}} \pm 0.00$ \\
\hline \multirow[t]{2}{*}{ S6 } & $\mathrm{F}$ & $7.54^{\mathbf{b}_{ \pm}} \pm 0.01$ & $2250^{\mathbf{b}_{ \pm}} \pm 10.00$ & $7.50^{\mathbf{e}} \pm 0.08$ & $1.85^{d} \pm 1.85$ & $0.72^{\mathbf{e}_{ \pm}} 0.09$ & $0.01^{d} \pm 0.00$ & $0.03^{c} \pm 0.00$ \\
\hline & M & $7.31^{c} \pm 0.17$ & $2136.5^{\mathbf{b}} \pm 3.50$ & $8.92^{d} \pm 0.02$ & $1.66^{\mathbf{e}_{ \pm}} 0.83$ & $0.41^{\mathbf{e}_{ \pm}} 0.04$ & $0.01^{d} \pm 0.00$ & $0.05^{\mathbf{c}} \pm 0.00$ \\
\hline \multicolumn{9}{|c|}{ Significance } \\
\hline \multicolumn{2}{|c|}{ Total effect of disturbance (A) } & $* * *$ & $* * *$ & $* * *$ & $* * *$ & $* * *$ & $* * *$ & * \\
\hline \multicolumn{2}{|c|}{ Total effect of sampling time (B) } & NS & $* * *$ & $* * *$ & $* * *$ & $* * *$ & NS & $* * *$ \\
\hline \multicolumn{2}{|c|}{$A \times B$} & $* * *$ & $* * *$ & $* * *$ & $* * *$ & $* * *$ & $* * *$ & * \\
\hline
\end{tabular}

The values are denoted as mean \pm standard error $(n=3)$. Values with the same letters within each column indicate no significant difference ( $p<0.05)$ by Tukey test. NS not significant, ${ }^{*} p<0.05$ significant differences, ${ }^{* *} p<0.001$ highly significant differences using two-way ANOVA and Tukey test, $E C$ electrical conductivity in ( $\mu$ s/ $\mathrm{cm}), \mathrm{H}$ humidity in (\%); TOC: Total organic carbon in (\% C); $\mathrm{NH}_{4}-\mathrm{N}$ : Ammonium nitrogen in (\%); $\mathrm{NO}_{3}-\mathrm{N}$ : Nitrate nitrogen in (\%); $P \mathrm{O}_{4}-\mathrm{P}$ : available phosphorus in (mg/g soil). F: February; $M$ : May. $\mathrm{PO}_{4^{-}} \mathrm{P}$ available phosphorus in (mg/g soil), $F$ February, $M$ May

by treated wastewater (S5, 12 taxa) or groundwater (S3, 10 taxa) while the lowest one was observed in landfill soil (S4, 1 taxa) and mining soil (S6, 3 taxa). The twoway ANOVA showed a significant effect $(p<0.05)$ of the sampling time on the cyanobacterial diversity of the agricultural soils (Fig. 3a). However, no significant effect of sampling time on diversity was observed in heavily anthropized soils. The three genera Phormidium (9 taxa), Pseudanabaena (4 taxa), and Leptolyngbya (4 taxa) were the most represented (Fig. 3c). In order of occurrence, the common species present in most soil were Phormidium crassivaginatum, Phormidium autumnale,

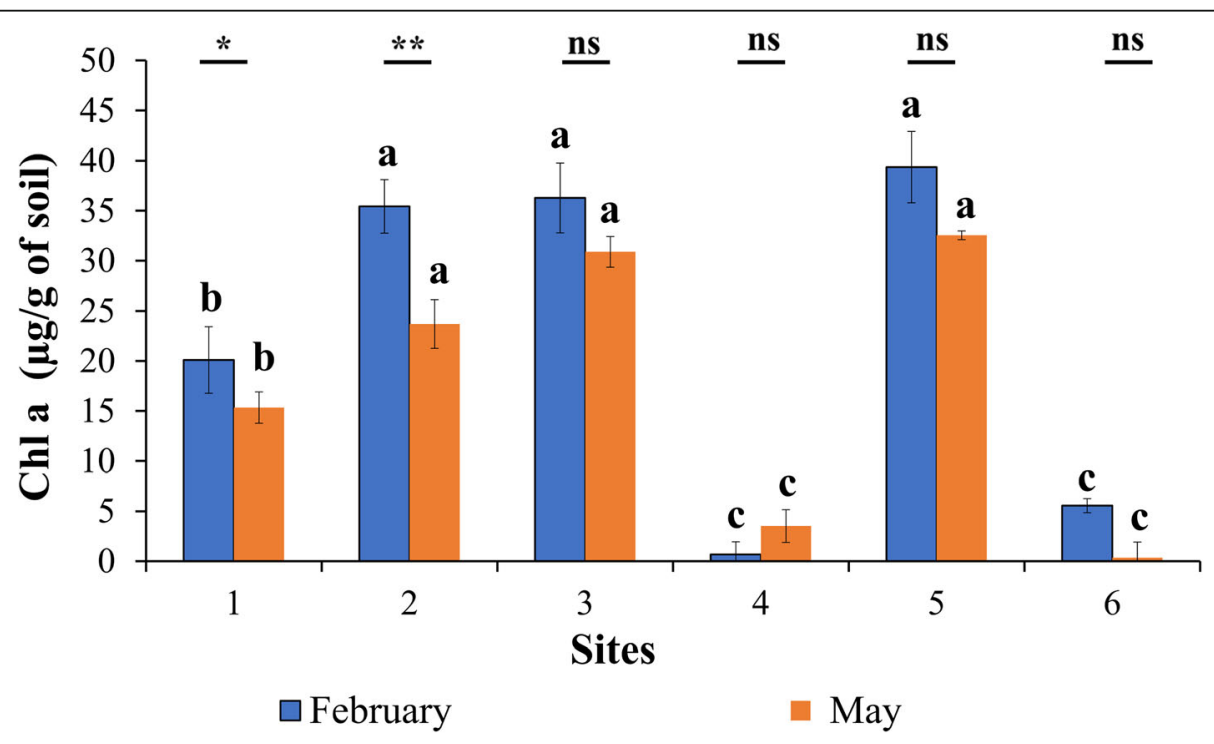

Fig. 2 Chlorophyll a concentration $(\mu \mathrm{g} / \mathrm{g}$ soil) in soil microalgae. Data are means \pm standard error $(n=3)$. Different letters indicate significant differences ( $p<0.05$ by Tukey's HSD test) between sampled sites. NS: not significant; ${ }^{*} p<0.05$ significant difference; ${ }^{* *} p<0.001$ highly significant difference using tow-way ANOVA and Tukey test 
Table $\mathbf{3}$ Inventory of cyanobacteria taxa in the study sites

\begin{tabular}{|c|c|c|c|c|c|c|c|c|c|c|c|c|}
\hline \multirow[t]{2}{*}{ Taxa } & \multicolumn{2}{|l|}{ S1 } & \multicolumn{2}{|c|}{ S2 } & \multicolumn{2}{|l|}{ S3 } & \multicolumn{2}{|c|}{ S4 } & \multicolumn{2}{|l|}{ S5 } & \multicolumn{2}{|c|}{ S6 } \\
\hline & $F$ & $\mathbf{M}$ & $F$ & M & $\mathbf{F}$ & M & $F$ & M & $\mathbf{F}$ & $\mathbf{M}$ & $\mathrm{F}$ & M \\
\hline \multicolumn{13}{|l|}{$\begin{array}{l}\text { Order/Oscillatoriales } \\
\text { F/ Phormidiaceae }\end{array}$} \\
\hline Phormidium crassivaginatum An. et Kom. (PCRA) & & + & + & + & & + & & & + & & & \\
\hline Phormidium articulatum Clau. (PART) & & & + & + & + & + & & & & & & \\
\hline Phormidium attenuattum An. et Kom. (PATT) & & & + & + & & & & & & & & \\
\hline Phormidium koprophilum An. (PKOP) & & & & & + & & & & & & & \\
\hline Phormidium formosum (Bory.) An. (PFOR) & & & & & & & & & + & & & \\
\hline Phormidium Iusitanicum An. (PLUS) & & & & & & & & & + & & & \\
\hline Phormidium autumnale (Ag.) Trev. (PAUT) & + & + & + & + & + & + & & & + & + & & \\
\hline Phormidium chlorinum An. (PCHL) & & & & & & & & & + & & & \\
\hline Phormidium sp1 (Psp1) & & & & & + & & & & & & + & \\
\hline Pseudophormidium flexuosum An. and Kom. (PSFLE) & & & + & & & & & & & & & \\
\hline \multicolumn{13}{|l|}{ F/Pseudanabaenaceae } \\
\hline Pseudanabaena minima An. (PMIN) & & & & & & & & & + & & & \\
\hline Pseudanabaena balatonica Sche. And Kol. (PBAL) & & & + & & & & & & & & & \\
\hline Pseudanabaena galeata Böch. (PGAL) & & & & & + & & & & + & & & \\
\hline Pseudanabaena mucicola (Hub. and Naum.) Sch. (PMUC). & + & & & & & & & & & & & \\
\hline Jaaginema quadripunctulatum (Bru.et Bis.) An. and Kom. (JQUA) & & & & & & & & & & + & & \\
\hline Leptolyngbya faveolarum (Rab.) An. and Kom. (LFAV) & & & + & & & & & & + & & & \\
\hline Leptolyngbya benthonica (Sku.) An. (LBEN) & & & + & & & & & & & & & \\
\hline Leptolyngbya henningsii (Lemm.) An. (LHEN) & + & & & & & & & & + & & & \\
\hline Leptolyngbya sp. (Lsp1) & & + & + & & + & + & & & & & & \\
\hline \multicolumn{13}{|l|}{ F/Oscillatoriaceae } \\
\hline Oscillatoria rupicola Han. (ORUP) & + & & & & + & & & & + & & & \\
\hline Oscillatoria sancta Kütz. (OSAN) & & + & & & + & + & & & & + & & \\
\hline Lyngbya sp (Lsp. (LYsp) & & & & & & & & & + & & + & + \\
\hline \multicolumn{13}{|l|}{$\begin{array}{l}\text { O/Chroococcales } \\
\text { F/Merismopediaceae }\end{array}$} \\
\hline Synechocystis sp. (Ssp) & & & & + & + & + & & & & + & + & + \\
\hline Synechococcus sp. (SYsp) & & & & & & & + & + & & & & \\
\hline Aphanocapsa sp. (Asp) & + & & & + & + & & & & + & + & & \\
\hline Number of taxa/site & 5 & 4 & 9 & 6 & 10 & 6 & 1 & 1 & 12 & 5 & 3 & 2 \\
\hline
\end{tabular}

(+) presence, F February, M May

Synechocystis sp, and Aphanocapsa sp (4 sites), Leptolyngbya sp, Oscillatoria rupicola, and Oscillatoria sancta (3 sites) while Phormidium articulatum, Pseudanabaena galeata, Leptolyngbya faveolarum, Leptolyngbya henningsii, and Lyngbya sp were represented only in few specific soils (2 sites).

Among the 25 taxa identified, it is important to note that for 6 taxa, morphological taxonomic identification has been stopped at the genus level. Other modern identification techniques (molecular and polyphasic approach) are still needed to confirm the precise identity of these taxa. Seven species of soil cyanobacteria were successfully isolated from the soils investigated and cultivated in the laboratory. These species were Phormidium articulatum, Pseudanabaena balatonica, Lyngbya sp., Leptolyngbya faveolarum, Oscillatoria rupicola, Oscillatoria sancta, and Synechocystis sp. (Fig. 4).

\section{Multivariate Analysis}

A principal component analysis (PCA) was performed on a data matrix consisting of 7 variables (conductivity, $\mathrm{pH}$, soil moisture, available phosphorus, ammonium nitrogen, nitrate nitrogen, TOC) and 25 individuals 


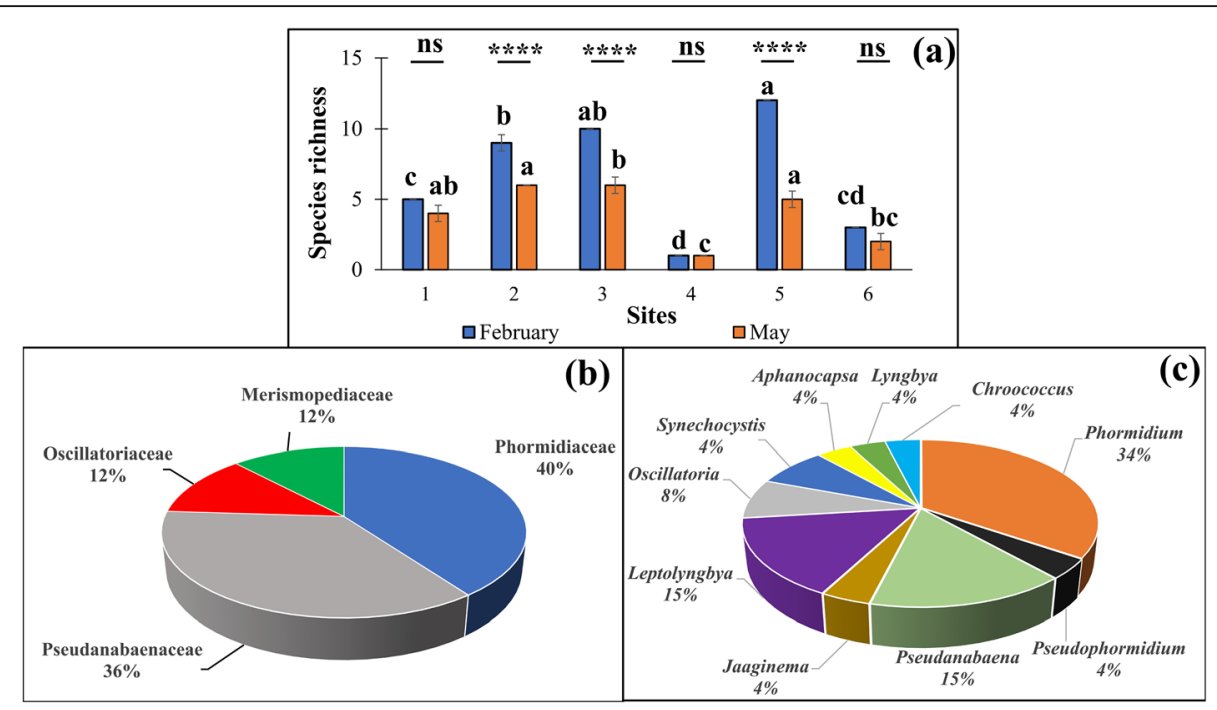

Fig. 3 Species richness (a), spectrum families (b), and spectrum genera (c) of cyanobacteria in the studied soils. Data are means \pm standard error $(n=3)$. Different letters (3a) indicate significant differences ( $p<0.05$ by Tukey's HSD test) between sampled sites, NS: not significant; ${ }^{*} p<0.05$ significant difference; *** $p<0.001$ highly significant difference using two-way ANOVA and Tukey test

(species) distributed along the six investigated sites. A PCA-ordination diagram is shown in Fig. 5. The variables were mainly associated with two axis (F1 and F2) in which $49.08 \%$ of the total variance in the data was found.

The first axis F1 with $29,52 \%$ of total variance was strongly associated on the positive side with soil moisture. The second axis $\mathrm{F} 2$ with $19.56 \%$ was positively associated with conductivity, ammonium nitrogen, nitrate nitrogen, TOC and available phosphorus contents. The PCA analysis results showed that the group of taxa Phormidium crassivaginatum (PCRA), Phormidium articulatum (PART), Phormidium attenuattum (PATT), Phormidium autumnale (PAUT), Leptolyngbya sp. (Lsp), Synechocystis sp. (Ssp), and Aphanocapsa sp. (Asp) was highly associated to soil moisture. However, the taxa Phormidium koprophilum (PKOP), Phormidium formosum (PFOR), Phormidium lusitanicum (PLUS), Phormidium chlorinum (PCHL), Pseudanabaena minima (PMIN), Pseudanabaena galeata (PGAL), Leptolyngbya faveolarum (LFAV), Leptolyngbya benthonica (LBEN), and Leptolyngbya henningsii (LHEN) showed the highest association to

Table 4 Importance of taxonomic level of cyanobacteria in studied soils

\begin{tabular}{lllll}
\hline \multirow{2}{*}{ Order } & \multicolumn{4}{l}{ Taxonomic level } \\
\cline { 2 - 5 } & Family & Genera & Species & Total (\%) \\
\hline Oscillatoriales & 3 & 7 & 22 & 88 \\
O/Chroococcales & 1 & 3 & 3 & 12 \\
Nostocales & 0 & 0 & 0 & 0 \\
Total & 4 & 10 & 25 & 100 \\
\hline
\end{tabular}

ammonium nitrogen $\left(\mathrm{NH}_{4}-\mathrm{N}\right)$, nitrate nitrogen $\left(\mathrm{NO}_{3}-\mathrm{N}\right)$, available phosphorus content $\left(\mathrm{PO}_{4}-\mathrm{P}\right)$, and total organic carbon (COT). Finally, the taxa Phormidium sp. (Psp), Pseudophormidium flexuosum (PSFLE), Pseudanabaena balatonica (PBAL), Pseudanabaena mucicola (PMUC), Jaaginema quadripunctulatum (JQUA), Oscillatoria rupicola (ORUP), Oscillatoria sancta (OSAN), Lyngbya sp. (LYsp), and Synechococcus (SYsp) sp. (SYsp) showed the highest association to $\mathrm{pH}$ and conductivity (EC).

In addition, a cluster analysis was used to separate species into distinct groups according to environmental factors. Three groups of taxa can be distinguished from the dendrogram on the basis of the hierarchical cluster (Fig. 6).

I. Taxa with a positive association just to soil moisture. This first group includes the taxa of soil control (Reference site S1).

II. Taxa with the highest association to ammonium nitrogen, available phosphorus content, and total organic carbon. This second group includes taxa of soils irrigated with groundwater and treated wastewater (S3 and S5). This group includes cyanobacteria that appeared to be more tolerant to polluted and fertilized soils and positively associated with organic matter, TOC, available phosphorus, $\mathrm{NO}_{3}-\mathrm{N}$, and $\mathrm{NH}_{4}-\mathrm{N}$.

III. Taxa with positive association to $\mathrm{pH}$ and conductivity. This third group includes soils of S4 and S6 polluted by municipal and mine solid waste, respectively. These soils show a very low diversity of cyanobacteria including tolerant taxa to extreme environments (e.g., salty and heavily metal contaminated soils) such as Synechocystis sp., Phormidium sp., Lyngbya sp., and Oscillatoria sp. 


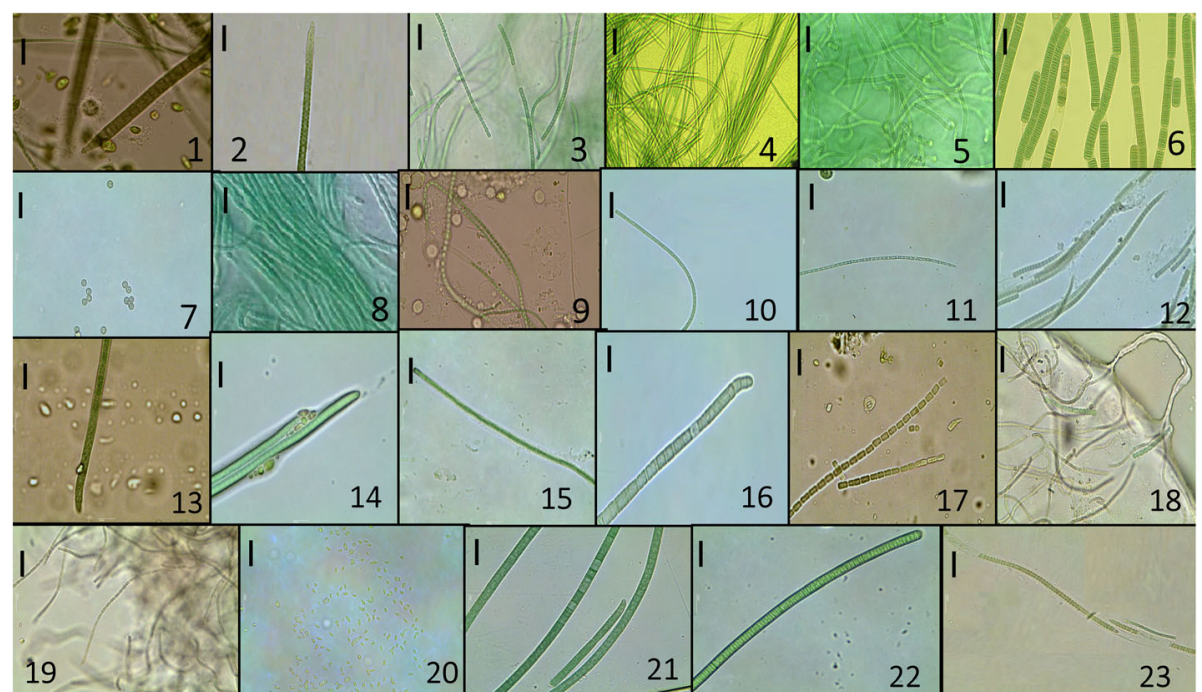

Fig. 4 Microphotographs of identified cyanobacterial strains. 1 Phormidium autumnale, 2 Phormidium crassivaginatum, 3 Pseudanabaena balatonica, 4 Phormidium articulatum, 5 Leptolyngbya faveolarum, 6 Lyngbya sp., 7 Synechocystis sp, 8 Leptolyngbya sp 1, 9 Leptolyngbya henningsii, 10 Jaaginema quadripunctulatum, 11 Leptolyngbya benthonica, 12 Pseudophormidium flexuosum, 13, Phormidium attenuattum, 14 Phormidium koprophilum, 15 Phormidium formosum, 16 Phormidium lusitanicum, 17 Pseudanbaena minima, 18 Pseudanabaena galeata, 19 Pseudanabaena mucicola, 20 Synechococcus sp., 21 Oscillatoria sancta, 22 Oscillatoria rupicola, 23 Phormidium sp. scale bar $=10 \mu \mathrm{m}$

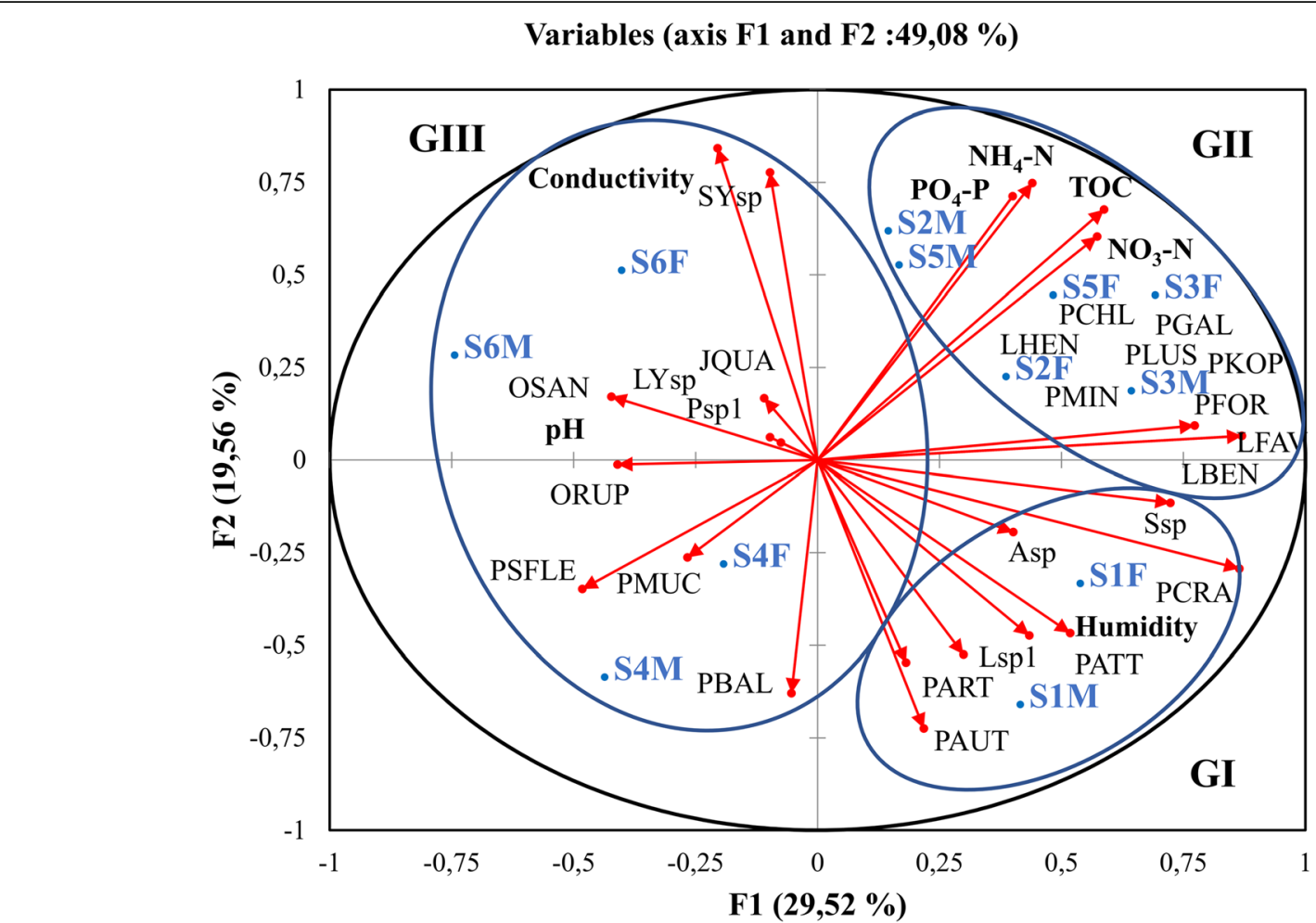

Fig. 5 PCA ordination analysis and projection of variables (physicochemical parameters and cyanobacteria taxa) and sampling sites (in blue) on the factoriel level $(1 \times 2)$. The PCA ordinations were constructed from a distance matrix of environmental variables. The visually categorized 3 groups in the PCA plot based on the arrow direction and the geometric angles between them (the more variables are correlated, the more their arrows point in the same direction; thus, the correlation coefficient is symbolized by the geometric angles between the arrow). Circles show selected groups. Species abbreviations are given in Table 3 


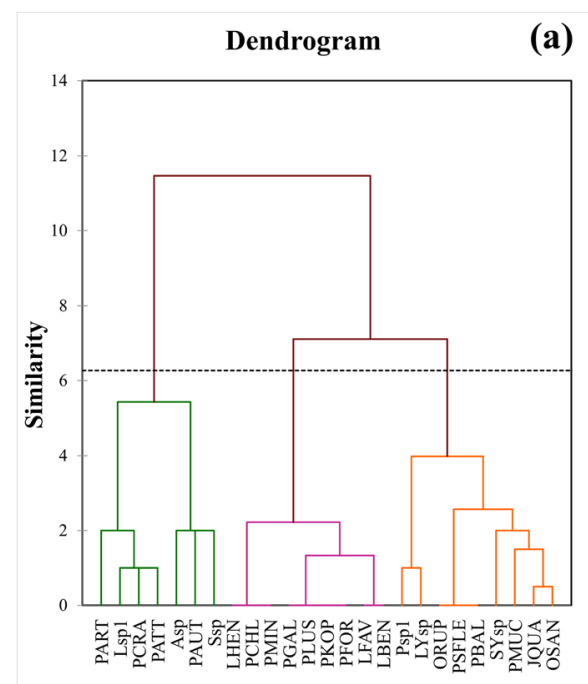

(a)

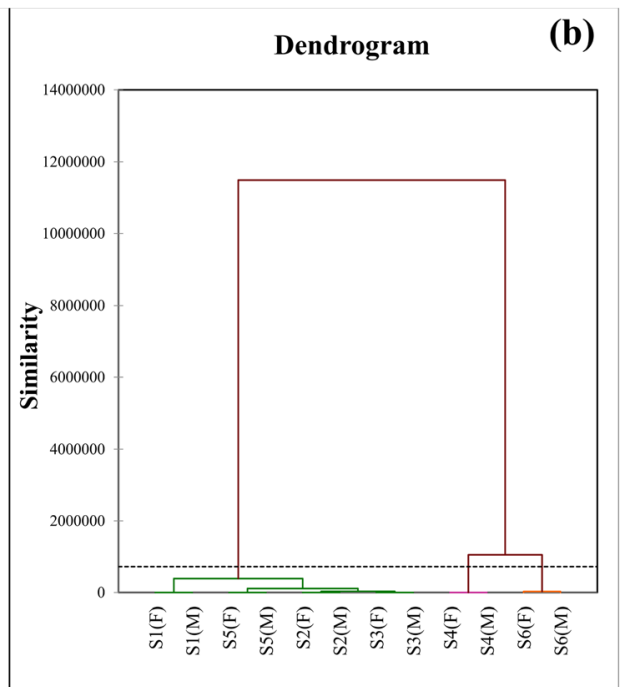

Fig. 6 Hierarchical clustering analysis using Ward's method and Euclidean distance matrix. Clusters of accessions of cyanobacteria species groups (a) and sampling sites (b) were formed on the basis of soil physicochemical similarity; the graph representing classification is a dendrogram of similitude with standardized Euclidean distances representing the closest accessions in homogeneous groups

The PCA results showed that the studied urban soils were ordered along two gradients. A gradient of drought represented by the first component (axis F1 represented by soil moisture). A second gradient of pollution and soil salinization represented by the second main component (axis F2 represented by TOC, ammoniumacal, nitrate nitrogen, available phosphorus, $\mathrm{pH}$, and conductivity) highlighting the impact of human activities on the spatial distribution of cyanobacteria.

\section{Discussion}

The cyanobacterial diversity is regulated by many environmental factors, including anthropogenic activities across temporal and spatial scales (Büdel et al. 2016). The soil physicochemical proprieties are considered as one of the most important factors influencing composition and distribution of cyanobacterial communities. The results of the PCA analysis showed that the soil physicochemical properties along the increasing urbanization gradient (site 1 to 6) were significantly influenced by different types of land use. Agricultural practices (wastewater irrigation, fertilizers and organic manure input), discharges of domestic and mining solid waste induce a spatial variability in the soil moisture, $\mathrm{pH}$, conductivity, nutrients $(\mathrm{N}, \mathrm{P})$, and organic matter (expressed as TOC) contents. Our results showed that the chemical composition of anthropized soils was significantly influenced compared to the soil control and natural rural soils (Hakkoum et al. 2020). Thus, the irrigated agricultural soils were significantly more humid, slightly acidic with higher TOC, organic matter, ammonium and nitrate nitrogen, and available phosphorus contents in comparison with non-cultivated soil (reference site). However, the soils affected by domestic or mine solid waste were significantly driest, more salinized, and probably contaminated with metals. These results are consistent with those of El Khalil et al. (2013) who have measured significant concentrations of $\mathrm{P}_{2} \mathrm{O}_{5}$ and $\mathrm{CaO}$ in the urban soils of Marrakesh. They attributed these high contents to anthropogenic inputs of phosphorus $(\mathrm{P})$ and technic materials, mainly building materials composed of cement and gypsum. They also showed that soils collected from agricultural areas irrigated with urban wastewater and soils developed on rubbish dumps are the most contaminated by metals (e.g., $\mathrm{Cu}, \mathrm{Zn}$, and $\mathrm{Pb}$ ). These results highlighted that the chemical properties of Marrakesh suburban soils were essentially influenced by the type of human practices, which causes more changes in soil chemical composition and structure in comparison with natural soils.

Previous studies have shown that human land uses practices induce changes of the soil environmental variables such as moisture, $\mathrm{pH}$, organic matter, and nutrient contents which influenced cyanobacterial diversity and distribution in urban soils (Trzcińska and PawlikSkowrońska 2008; Alghanmi and Jawad 2018; Rai et al. 2018). However, the great majority of studies on soil cyanobacterial communities have been carried out in natural environment (Büdel et al. 2016; Muñoz-Martín et al. 2019; Hakkoum et al. 2020) while those in urban and suburban soils still rather rare especially in southern Mediterranean drylands. Consequently, little is known about the biological diversity of urban soils in these areas. To the best of our knowledge, the present study 
constitutes the first attempt to investigate cyanobacterial diversity and ecology in urban soil of Morocco and assess the impact of different types of land use on their composition and spatial variability. Our investigations have revealed a diversity of 25 cyanobacterial taxa, distributed on two orders, four families, and ten genera. Although morphological method based on culturedependent approach and light microscopy has several limitations and are not always sufficient to validate cyanobacteria identification (Komárek and Anagnostidis 1989; Kumari et al. 2009), it continues to be necessary to identify cyanobacterial species, improve taxonomic resolution, and even diversity coverage (Choi et al. 2017). Nevertheless, the 16S rDNA sequencing method (as culture-independent approach) remains the most decisive and accepted tool (Patzelt et al. 2014) as it leads to a more precise identification, and it can be used to study both cultured and uncultured diversity (Rego et al. 2019). The benefit of this culture-independent approach is to confirm the morphological identification and also to identify other unculturable soil cyanobacteria species. However, the disadvantage of the molecular method are the systematic biases in DNA extraction or the $16 \mathrm{~S}$ primers that may miss taxa that can be revealed by the culture approach (Klappenbach et al. 2000; Zielinska et al. 2017). In this context, Rego et al. (2019) have shown that culture-dependent method was able to retrieve taxa that were not detected in any of the pyrosequencing data. To accurately identify cyanobacterial strains, an integrative approach (polyphasic approach) should be considered (Komárek 2013). This approach combines classical morphological methods with modern molecular phylogenetic analyses to improve the coverage of the cyanobacterial diversity and to retrieve both abundant and rare members of the communities (Rego et al. 2019; Sommer et al. 2020).

Though we only used morphological identification and culture-based method in this study, the cyanobacterial species richness is relatively high and represents a substantial knowledge of urban soil biodiversity in Moroccan and North African drylands. A comparative analysis of the total cyanobacteria richness revealed a great similarity with other works in various urban areas. Dorokhova et al. (2015) have found 14 taxa in the Northwestern Administrative District of Moscow (Russia); Maltsev et al. (2017) have reported 21 taxa in the soils of the Henichesk urboecosystems (Ukraine); Shekhovtseva (2014) has inventoried 7 taxa in urban ecosystems of the city of Mariupol (Ukraine) and Rai et al. (2018) have found 22 taxa in the soils of the city of Varanasi (India). In the studied urban soils, the Oscillatoriales are the most diverse order, followed by the Chroococcales. The Nostocales order (heterocytous forms) was completely absent. Řeháková et al. (2011) noted that the Oscillatoriales are generally more abundant in soils that contain relatively high concentrations of organic matter. In contrast, the Chroococcales, as unicellular or colonial microorganisms, do not require a stable substrate with a high organic matter content. It has been found that in urban soil, there are a large number of nonheterocyst forms, because the urban pollutants negatively affect the sensitivity of nitrogenase of nitrogen-fixing cyanobacteria; therefore, their reproduction is limited under such conditions (Domracheva et al. 2013). Furthermore, due to higher nitrate and ammonium nitrogen contents in irrigated soils with treated wastewater, the nitrogenase activity of heterocytous cyanobacteria can be inhibited. Our results showed that two families of Oscillatoriales (Pseudanabaenaceae and Phormidiaceae) constitute the dominant part with more than $76 \%$ of all taxa. The Phormidiaceae (40\%) was slightly more abundant than Pseudanabaenaceae (36\%). Blagodatnova and Bachura (2015) have indicated that in the urban soils, the cyanobacterial taxonomic structure is dominated by the family of Phormidiaceae.

With regard to specific diversity, cyanobacteria in studied urban soils consist mainly of coccoid forms of the Chroococcales (Synechococcus, Aphanocapsa, Synechocystis) and filamentous forms of the Oscillatoriales (Leptolyngbya, Lyngbya, Oscillatoria, and Phormidium). These cyanobacteria are able to construct slimy sheaths and were most frequently found in the urban ecosystems (Gerasimenko and Gorovtsov 2014). The cyanobacterium Lyngbya was distinctly present in the soil irrigated by treated wastewater and mining soil. This may be due to the presence of denser sheaths that aid these cyanobacteria survive in disturbed soils (Gerasimenko and Gorovtsov 2014). In the reference site and agricultural soil, Leptolyngbya was extant. This cyanobacterium has an ability to build very dense, robust films, that might show the potential in bonding top layer of soil. The literature shows that this genus is dominant in nonviolated dry habitats (Alwathnani and Johansen 2011). Phormidium autumnale was the most widely represented species in the studied urban soils. It is well known that this species has a high tolerance to anthropogenic stress and can withstand extreme environmental conditions (Gorovtsov et al. 2017). Whereas the genus Jaaginema was typical for soils with an alkaline reaction (Blagodatnova and Bachura 2015).

As in many soil worldwide, non-heterocytous filamentous cyanobacteria were major components of urban soils in Marrakesh arid area. Indeed, these cyanobacteria have a large ecological distribution and appear to be the most frequent in the studied urban soils. Numerous taxa were omnipresent and have been reported in at least four different sites. Among these species, we find Aphanocapsa sp., Phormidium crassivaginatum, Phormidium autumnale, and Synechocystis sp. which were the most abundant in all studied agricultural soils (S3 and S5). These taxa are cosmopolitan and widespread in various types 
of soils (Song et al. 2005; Begum et al. 2008). In contrast, heterocytous genera such as Scytonema, Tolypothrix, Nostoc, and Cylindrospermum were only rarely present. These species are known to be particularly sensitive to human disturbances such as tillage, pollution, and pesticides input, which are commonly applied in farmlands (Zancan et al. 2006). This might be the reason for their absence from the studied farmlands soils.

The results showed that cyanobacteria taxa exist in all investigated soils, but they reveal significant differences between soils with a significant diversity in irrigated agricultural soils S3 and S5 (10 and 12 taxa, respectively). This diversity could be explained by the high content of moisture, organic carbon, and nutrients. The soils irrigated with treated wastewater or groundwater had the maximum moisture content $(18.58 \%$ and $26.04 \%$, respectively) and were more concentrated in TOC (6.66\% and 5.26\%), $\mathrm{PO}_{4}-\mathrm{P}(1.28 \mathrm{mg} / \mathrm{g}$ and 1.03 $\mathrm{mg} / \mathrm{g}), \mathrm{NO}_{3}-\mathrm{N}(0.15 \%$ and $0.13 \%)$, and $\mathrm{NH}_{4}-\mathrm{N}(0.12 \%$ and $0.10 \%)$ compared to non-cultivated and unirrigated reference soil. Well water irrigation (combined with chemical and organic fertilizers) or treated wastewater irrigation provides water, organic matter, and nutrients such as nitrogen and phosphorus as well as other minerals to soil (Minz et al. 2011). Soils irrigated with wastewater had been demonstrated to harbor $4.1 \%$ of organic particles by weight, but these particles contained up to $41.7 \%$ of nitrogen and $47.8 \%$ of the total soil carbon, and thus represented an important storage of energy and nutrient for microorganisms (AL-Jaboobi et al. 2014). Numerous studies showed that these factors may have beneficial effects on soil microbial and cyanobacterial communities and provide favorable conditions for their growth and diversity (Fathi and Zaki 2003; Gans et al. 2005; Mohan and Kumar 2019). Zancan et al. (2006) and Lin et al. (2013) have demonstrated that cyanobacteria also have capacity to enhance productivity in a variety of agricultural situations as well as resilience to irrigation with water of different qualities.

The highest cyanobacterial richness of the studied urban soils occurred during the February campaign unlike other microalgae (e.g., diatoms) which are more diversified in May (Minaoui et al. 2021). This maximum diversity of cyanobacteria in winter can be explained by favorable soil physicochemical conditions (high soil moisture, high TOC, ammonium and nitrate nitrogen, and available phosphorus contents). These findings were in harmony with the results obtained by Kobbia et al. (1995) and Shanab (2006) who reported that the higher soil cyanobacterial diversity may be attributed to the high soil moisture, organic matter, and micronutrients contents. Our results suggest that soil moisture, $\mathrm{pH}$, TOC, organic matter, nutrients (ammonium nitrogen, nitrate nitrogen, and available phosphorus) contents and conductivity were the major environmental factors that drive cyanobacterial diversity and spatial variability in peri-urban soils of Marrakech. Indeed, the soil moisture, TOC, and nutrient contents were positively correlated with cyanobacteria diversity. Soil moisture was often considered as a limiting factor for cyanobacteria growth and microalgal biomass in soils (Lin et al. 2013; Mohamed and Abdel Hameed 2006). The high percent of TOC and consequently the abundance of organic matter detected in irrigated agricultural soils suggest that treated wastewater and the organic fertilizer supply can be significant sources of soil nutrient enrichment (nitrogen, phosphorus, and other nutrients). Due to its higher organic matter content, and consequently its abundance of bacteria, irrigation with treated wastewater can result in an increase in the activity of different soil microbial processes, including nitrification (Minz et al. 2011; Ibekwe et al. 2017). However, Rai et al. (2018) confirmed that nitrification and nitrogen oxidation are affected by the relatively high $\mathrm{pH}$ of the urban soil, resulting in a reduction in the inorganic nitrogen content $\left(\mathrm{NO}_{3}-\mathrm{N}\right)$ of urban soil as compared to rural soils. Other researchers have suggested that the concentration and quality of nutrients especially the availability of nitrates and phosphates are an important factor that favors the diversity and growth of cyanobacteria in soil ecosystems (Zancan et al. 2006).

Among soil properties, $\mathrm{pH}$ is a very important factor in growth and distribution of cyanobacteria, which have generally been reported to prefer neutral to slightly alkaline $\mathrm{pH}$ for optimum growth (Lukešová 2001). The $\mathrm{pH}$ values in all studied urban soils were higher than 7 and this might partially explain the wide spread of the inventoried cyanobacteria. Another factor that affects the repartition of soil cyanobacteria is soil salinization (expressed as soil conductivity). In the studied anthropogenic transect, the average values of electrical conductivity were ranged between 179.8 and $3175 \mu \mathrm{S} / \mathrm{cm}$. Our data showed that cyanobacteria diversity decreased with increasing soil conductivity, specifically in mine and landfill soils (S4 and S6). Salinity is known to diminish the growth of cyanobacteria and to favour salt-tolerant species (Whitton and Potts 2000; Rejmánková et al. 2004; Hokmolahi et al. 2017). In the former landfill soil (site 4), the saltiest one, only one taxon Synechococcus sp. was inventoried. This low cyanobacterial diversity was also confirmed by the very low algal biomass expressed as chl-a content. This could also be explained by the nature and dominance of technical and anthropic materials from waste resulting in the transformation of natural soil into a "Technosol" (El Khalil et al. 2013) unsuitable for the growth of cyanobacteria and microalgae. Schwartz et al. (2015) reported that most soils in urban environments, particularly anthropic and technical soils, 
are deficient in major nutritive elements such as $\mathrm{N}, \mathrm{P}$, and $\mathrm{K}$, highly compacted and anoxic hence are not well adapted to microalgae growth. Likewise, in the mining soil (S6), only three cyanobacteria species were found, Phormidium sp., Lyngbya sp., and Synechocystis sp. This mining soil was relatively saline $(2250 \mu \mathrm{S} / \mathrm{cm})$ and contains $\mathrm{Zn}(602.55 \mathrm{mg} / \mathrm{kg}), \mathrm{Cu}(216.36 \mathrm{mg} / \mathrm{kg})$, and $\mathrm{Pb}$ (343.92 mg/kg) (El Gharmali et al. 2004; Boujghad et al. 2019; El Alaoui et al. 2019). The extremely low cyanobacterial diversity and algal biomass (chl-a $0.36 \mu \mathrm{g} / . \mathrm{g}^{1}$ ) measured in this disturbed site could therefore be the result of the high content of heavy metals. Trzcińska and Pawlik-Skowrońska (2008c) confirmed that the diversity of soil microalgae in areas polluted by heavy metals was always very low. Our study suggests that most of the cyanobacteria identified in this mine soil are cosmopolitan and ubiquitous species (Trzcińska and PawlikSkowrońska 2008). A previous study demonstrated that the unicellular cyanobacterium Synechocystis sp. had the ability to accumulate $\mathrm{Pb}, \mathrm{Zn}$, and $\mathrm{Cu}$ (Rahman et al. 2011). Furthermore, some filamentous cyanobacteria such as Lyngbya sp. and Oscillatoria sp. have the capacity to resist to high content of $\mathrm{Zn}$ and $\mathrm{Pb}$ (Venter et al. 2015). Generally, several cyanobacteria species are able to grow in the presence of heavy metals as a result of a variety of tolerance mechanisms. For example, binding to cell wall due to metal adsorption onto the cell surface (wall, cell membrane, or external polysaccharides) and binding to cytoplasmic ligands, phytochelatins, and metallothioneins and other intracellular molecules (Keren et al. 2002; Chojnacka et al. 2005). Another mechanism is the sequestration and bioremoval of heavy metals by synthesis of metal-binding compounds such as phenolic compounds, organic acids, and proteins (Mehta and Gaur 2005; Shanab et al. 2012).

Microalgae including cyanobacteria are physiologically heterogeneous, making any generalization about their soil relations difficult (Fathi and Zaki 2003). However, it is well known that changes in physicochemical characteristics and edaphic factors of any soil, with some specific biological traits within the cyanobacteria themselves, constitute the main factors responsible for the abundance and diversity of soil microalgae (Fathi and Zaki 2003; Shekhovtseva and Mal'tseva 2015). Ultimately, this study demonstrated that cyanobacteria composition and community diversity varied significantly between the disturbed urban soils depending on different land use practices and water irrigation qualities. The strongly anthropized and technical soils (polluted by urban and mine solid wastes) record the lowest diversity of soil cyanobacteria and algal biomass. The cyanobacterial diversity in urban soils decreases as the human disturbance level increases. These first results suggest that cyanobacteria, as other microorganisms, could be used as an indicator of urban soil quality and their ecological status.

\section{Conclusion}

This exploratory survey highlighted the effect of different types of land use practices on suburban soil proprieties and cyanobacteria diversity and distribution along an increasing urbanization gradient in Marrakesh arid area. The physicochemical proprieties of suburban soils are significantly modified by their mode of usage and human activities. This survey provides a first inventory (25 taxa) of the urban soil cyanobacterial communities and shows their high sensitivity to the anthropogenic disturbances in Moroccan drylands. It reveals significant variations of cyanobacterial diversity and spatial variability in response to different land use impacts. The urban soils were characterized by urbanophilic/synanthropes cyanobacterial species (i.e., species highly associated with urban climate and human beings) such as Phormidium autumnale, Lyngbya sp., Leptolyngbya sp., Jaaginema sp., and Oscillatoria sp. Our results suggest that soil moisture, $\mathrm{pH}$, organic matter, nutrients $\mathrm{N}$ and $\mathrm{P}$ supply, and conductivity were the major environmental factors that drive cyanobacterial composition and distribution in peri-urban soils of Marrakech. The cyanobacterial diversity and microalgal biomass were significantly lower in the anthropized soils affected by municipal or mining solid wastes, while the input of organic matter and nutrients from irrigation with treated wastewater appears to be beneficial for the increasing the diversity of soil cyanobacteria. In this first report, the inventory of urban soil cyanobacteria was far from being complete in relation to existing potential. Further studies based on quantitative and molecular approaches are necessary to better understand the soil cyanobacterial composition and species responses to human disturbances and management of urban spaces. Other surveys will be also necessary to complete the soil cyanobacterial diversity and define more precisely their ecological trends in other Moroccan terrestrial arid environments.

\footnotetext{
Abbreviations

EC: Electrical conductivity; $\mathrm{H}$ : Humidity; TOC: Total organic carbon; $\mathrm{NH}_{4}{ }^{-}$ $\mathrm{N}$ : Ammonium nitrogen; $\mathrm{NO}_{3}-\mathrm{N}$ : Nitrate nitrogen; $\mathrm{PO}_{4}-\mathrm{P}$ : Available phosphorus; Chl-a: Chlorophyll a; PCA: Principal Component Analysis; S: Site; F: February; M: May

\section{Acknowledgements}

This work was supported by Water, Biodiversity and Climate change Laboratory, Faculty of Sciences Semlalia, University Cadi Ayyad, Marrakesh, Morocco. We are thankful to unknown reviewers for helping us to improve the manuscript rather considerably.
}

\section{Authors' contributions}

Conceptualization, M.L. and Z.H.; Methodology, Z.H., F.M., M.D., M.L., K. M.; Software, Z.H.; Validation, M.L.; Formal analysis, Z.H., M.L.; Data curation, Z.H., M.L.; Writing—original draft preparation, Z.H.; Writing—review and editing, 
Z.H, M.L.; Visualization, Z.H, M.L., F.M., M.D., K.M.; Supervision, M.L., M.D., K.M. The authors have read and agreed to the published version of the manuscript.

\section{Funding}

The authors did not receive support from any organization for the submitted work

\section{Availability of data and materials}

The datasets used and/or analyzed during the current study are available from the corresponding author on reasonable request.

\section{Declarations}

\section{Ethics approval and consent to participate}

Not applicable.

\section{Consent for publication}

Not applicable.

\section{Competing interests}

The authors declare that they have no competing interests.

\section{Author details}

'Laboratory of Water, Biodiversity and Climate Change; Phycology, Biotechnology and Environmental Toxicology Research Unit, Faculty of Sciences Semlalia Marrakesh, Cadi Ayyad University, Av. Prince My Abdellah, P.O. Box 2390, 40000 Marrakesh, Morocco. 'Laboratory of Chemistry, Modeling and Environmental Sciences, Polydisciplinary Faculty of Khouribga, Sultan Moulay Slimane University of Beni Mellal, B.P. 145, 25000 Khouribga, Morocco.

\section{Received: 17 November 2020 Accepted: 21 April 2021}

\section{Published online: 15 June 2021}

\section{References}

Abdel Hameed MS (2006) Survey of soil algal flora of some cultivated soils in Beni Suef, Egypt. Egypt J Phycol 7(1):1-15. https://doi.org/10.21608/egyjs.2 006.114130

AFNOR (1975) Standard T90-1110. Water test: determination of total Kjeldahl nitrogen.

AFNOR NF EN 13040 (2000) Soil improvers and growing media-preparation of samples for physical and chemical testing, determination of dry matte content, moisture content and laboratory compacted density. French Association of Normalization, AFNOR Editions, Paris, France

Alghanmi HA, Jawad HM (2018) Effect of environmental factors on cyanobacteria richness in some agricultural soils. Geomicrobiol J 36(1):75-84. https://doi. org/10.1080/01490451.2018.1517196

AL-Jaboobi M, Tijane M, EL-Ariqi S, El Housni A, Zouahri A, Bouksaim M (2014) Assessment of the impact of wastewater use on soil properties. J Mater Environ Sci 5(3):747-752

Alwathnani H, Johansen JR (2011) Cyanobacteria in soils from a Mojave Desert ecosystem. Monogr West North Am Nat 5(1):71-89

Anagnostidis K, Komarek J (1990) Modern approach to the classification system of cyanophytes. 5. Stigonematales. Algolo Stud 86:1-74

Aubert G (1978) Soil analysis methods. CRDP Edition, Marseille. 360 pp.

Bag P, Ansolia P, Mandotra S K, Bajhaiya AK (2019) Potential of blue-green algae in wastewater treatment. In: Gupta SK, Bux F (eds.) Application of Microalgae in Wastewater Treatment. Springer, Cham. https://doi.org/10.1007/978-3-03 0-13913-1_17

Bardgett RD, Usher MB, Hopkins DW (2005) Biological diversity and function in soils. Cambridge University Press. https://doi.org/10.1017/CBO9780511541926

Barragán C, Carlos E, Wetzel CE, Ector L (2017) A standard method for the routine sampling of terrestrial diatom communities for soil quality assessment. J Appl Phycol 30(2):1095-1113. https://doi.org/10.1007/s10811-017-1336-7

Begum ZT, Mandal R, Amin FB (2008) Quantification and nitrogen fixation of cyanobacteria in rice field soils of Bangladesh. Bangladesh J Bot 37(2):183-188

Belnap J, Phillips SL, Witwicki DL, Miller ME (2008) Visually assessing the level of development and soil surface stability of cyanobacterially dominated biological soil crusts. J Arid Environ 72(7):1257-1264. https://doi.org/10.1016/J. jaridenv.2008.02.019
Blagodatnova AG, Bachura YM (2015) Phytocenotic structure of groups of soil algae and cyanobacteria of urban lawns (on the example of Novosibirsk and the city of Gomel. Bull Novosibirsk State Pedagogical Univ 25:82-93 (in Russian). doi: https://doi.org/10.15293/2226-3365.1502.08

Boujghad A, Bouabdli A, Baghdad B (2019) Groundwater quality evaluation in the vicinity of the Draa Sfar Mine in Marrakesh, Morocco. Euro-Mediterr J Environ Integr 4:12. https://doi.org/10.1007/s41207-018-0096-3

Briones MJI (2014) Soil fauna and soil functions: a jigsaw puzzle. Front Environ Sci 2:7

Büdel B, Dulic T, Darienko T, Rybalka N, Friedl, T (2016). Cyanobacteria and algae of biological soil crusts. In: Weber B, et al. (eds.) Biological soil crusts: an organizing principle in drylands. Ecological Studies 226. Springer, Cham, pp. 55-80

Carrino-Kyker SR, Swanson AK, Burke DJ (2011) Changes in eukaryotic microbial communities of vernal pools along an urban-rural land use gradient. Aquat Microb Ecol 62(1):13-24. https://doi.org/10.3354/ame01432

Caruso T, Migliorini M, Rota E, Bargagli R (2017) Highly diverse urban soil communities: does stochasticity play a major role? Appl Soil Ecol 110:73-78. https://doi.org/10.1016/j.apsoil.2016.10.012

Choi J, Yang F, Stepanauskas R, Cardenas E, Garoutte A, Williams R, Flater J, Tiedje JM, Hofmockel KS, Gelder B, Howe A (2017) Strategies to improve reference databases for soil microbiomes. ISME J 11(4):829-834. https://doi.org/10.103 8/ismej.2016.168

Chojnacka K, Chojnacki A, Gorecka H (2005) Biosorption of $\mathrm{Cr}^{3+}, \mathrm{Cd}^{2+}$ and $\mathrm{Cu}^{2+}$ ions by blue-green algae Spirulina sp.: Kinetics, equilibrium and the mechanism of the process. Chemosphere 59(1):75-84. https://doi.org/10.101 6/j.chemosphere.2004.10.005

Domracheva L, Kondakova L, Zykova J, Efremova V (2013) Cyanobacteria of urban soils. Princ Ecol 8(4):10-27. https://doi.org/10.15393/j.art.2013.3101

Dorokhova MF, Kosheleva NE, Terskaya EV (2015) Algae and cyanobacteria in soils of Moscow. Am J Plant Sci 6(15):2461-2471. https:/doi.org/10.4236/ajps.2015.615248

Douma M (2010) Biodiversité des Cyanobactéries des zones humides continentales du Maroc : taxonomie, distribution géographique, écologie, phylogénie et potentiel toxique. PhD thesis. Université Cadi Ayyad, Marrakech

El Alaoui A, Bechtaoui N, Benidire L, El Gharmali A, Achouak W, Daoui K et al (2019) Growth and heavy metals uptake by Vicia faba in mining soil and tolerance of its symbiotic rhizobacteria. Environ Prot Eng 45(1). https://doi. org/10.37190/epe190107

El Faïz M (2002) Marrakech: Patrimoine en péril. Actes Sud / Eddif, France, p 188

El Gharmali A, Rada M, El Adnani N, Tahlil M, El Meray A, Nejmeddine A (2004) Impact of acid mining drainage on the quality of superficial waters and sediments in the Marrakesh region, Morocco. Environ Technol 25(12):14311442. https://doi.org/10.1080/09593332508618463

El Khalil H, Schwartz C, El Hamiani O, Kubinick J, Morel JL, Boularbah A (2013) Distribution of major elements and trace metals as indicators of technosolisation of urban and suburban soils. J Soils Sediments 13(3):519530. https://doi.org/10.1007/s11368-012-0594-x

Fathi AA, Zaki FT (2003) Preliminary survey of edaphic algae in El-Minia region, Nile valley, Egypt. Egypt J Phycol 4(2):131-148. https://doi.org/10.21608/ egyjs.2003.113478

Foets J, Stanek-Tarkowska J, Teuling AJ, Van de Vijver B, Wetzel CE, Pfister L (2021) Autecology of terrestrial diatoms under anthropic disturbance and across climate zones. Ecol Indic 122:107248. https://doi.org/10.1016/j. ecolind.2020.107248

Gans J, Wolinsky M, Dumbar J (2005) Computational improvements reveal great bacterial diversity and high metal toxicity in soil. Science 309(5739):13871390. https://doi.org/10.1126/science.1112665

Garcia-Pichel F, Felde VJMNL, Drahorad SL, Weber B (2016) Microstructure and weathering processes within biological soil crusts. In: Biological soil crusts: an organizing principle in drylands. Springer, Cham, pp 237-255. https://doi. org/10.1007/978-3-319-30214-0_13

Gerasimenko A, Gorovtsov AV (2014) Taxonomic structure and quantity of soil cyanobacteria in urban soils of Volgodonsk city, Russia. Conference Paper (Modern scientific research: current theories and concepts). https://doi.org/1 0.13140/2.1.2804.5125

Gorovtsov A, Rajput VD, Gorbov S, Vasilchenko N (2017) Bioindication-based approaches for sustainable management of urban ecosystems. In: Green Technologies and Environmental Sustainability. Springer, Cham, pp 203-228

Guilland C, Maron PA, Damas O, Ranjard L (2018) Biodiversity of urban soils for sustainable cities. Environ Chem Lett 16(4):1267-1282. https://doi.org/10.1 007/s10311-018-0751-6

Hakkoum Z, Minaoui F, Douma M, Mouhri K, Loudiki M (2020) Diversity and spatial distribution of soil cyanobacteria along an altitudinal gradient in 
Marrakesh area (Morocco). Appl Ecol Env Res 18(4):5527-5545. https://doi. org/10.15666/aeer/1804_55275545

Hibti M (2001) Les amas sulfurés des Guemassa et des Jebilet (Meseta Sud Occidentale, Maroc): Témoins de l'hydrothermalisme précoce dans le bassin mésétien. Dissertation. Faculté des Sciences, Marrakech

Hokmolahi F, Riahi H, Soltani N, Shariatmadari Z, Hakimi MMH (2017) A taxonomic study on non-heterocystous filamentous Cyanoprokaryotes from soil of yazd province, Iran. Iran J Bot 23:1. https://doi.org/10.22092/ijb.2017.1 09312.1147

Ibekwe AM, Gonzalez-Rubio A, Suarez DL (2017) Impact of treated wastewater for irrigation on soil microbial communities. Sci Total Environ 622-623:16031610. https://doi.org/10.1016/j.scitotenv.2017.10.039

IBM Corp. Released (2013) IBM SPSS Statistics for Windows, Version 22.0. Armonk, NY: IBM Corp.

Joimel S, Schwartz C, Hedde M, Kiyota S, Krogh PH, Nahmani J et al (2017) Urban and industrial land uses have a higher soil biological quality than expected from physicochemical quality. Sci Total Environ 584:614-621

Kannan V, Vijayasanthi M, Chinnasamy M (2012) Bioremediation of chromium in tannery effluent by filamentous Cyanobacteria Anabaena flos-aquae West. Int J Environ Sci 2(4):2360-2366

Karthikeyan N, Prasanna R, Nain L, Kaushik BD (2007) Evaluating the potential of plant growth promoting cyanobacteria as inoculants for wheat. Eur J Soil Biol 43(1):23-30. https://doi.org/10.1016/j.ejsobi.2006.11.001

Keren N, Kidd MJ, Penner-Hahn JE, Pakrasi HB (2002) A light-dependent mechanism for massive accumulation of manganese in the photosynthetic bacterium Synechocystis sp. PCC 6803. Biochemistry 41(50):15085-15092. https://doi.org/10.1021/bi026892s

Klappenbach JA, Dunbar JM, Schmidt TM (2000) rRNA operon copy number reflects ecological strategies of bacteria. Appl Environ Microbiol 66(4):13281333. https://doi.org/10.1128/aem.66.4.1328-1333.2000

Kobbia IA, Metwali RM, El-Adel HM (1995) Studies on freshwater at Qaluobia province (Egypt) in relation to some physicochemical factors. Egypt J Bot 35(1):25-43

Komárek J (2013) Cyanoprokaryota. Teil 3: Heterocytous genera. Springer, Berlin Komárek J, Anagnostidis K (1989) Modern approach to the classification system of cyanophytes 4 Nostocales. Arch Hydrobiol Suppl 82:247-345

Komárek J, Anagnostidis K (1998) Cyanoprokaryota. 1. Chroococcales. Süsswasserflora von Mitteleuropa. Spektrum Verlag, Heidelberg, pp. 1-548

Komárek J, Anagnostidis K (2005) Cyanoprokaryota. Teil 2: Oscillatoriales. Elsevier, München

Kotai J (1972) Instructions for preparation of modified nutrient solution Z8 for algae. Norwegian Institute for Water Research, Blindern

Kumari N, Srivastava A, Bhargava P, Rai LL (2009) Molecular approaches towards assessment of cyanobacterial biodiversity. Afr J Biotechnol 8(18):4284-4298

Li B, Wu S, Zhou S, Wang T, Chen H (2017) Quantifying and mapping threats to soil biodiversity in Nanjing, China. Eur J Soil Biol 82:72-80. https://doi.org/1 0.1016/j.ejsobi.2017.08.007

Liao CF (1981) Devarda's alloy method for total nitrogen determination. Soil Sci Soc Am J 45(5):852-855. https://doi.org/10.2136/sssaj1981.03615995004500050005x

Lin CS, Chou TL, Wu JT (2013) Biodiversity of soil algae in the farmlands of midTaiwan. Bot Stud 54(1):41. https://doi.org/10.1186/1999-3110-54-41

Lukešová A (2001) Soil algae in brown coal and lignite post-mining areas in central Europe (Czech Republic and Germany). Restor Ecol 9(4):341-350. https://doi.org/10.1046/j.1526-100X.2001.94002.x

Maestre FT, Bowker MA, Cantón Y, Castillo-Monroy AP, Cortina J, Escolar C, Escudero A, Lázaro R, Martínez I (2011) Ecology and functional roles of biological soil crusts in semi-arid ecosystems of Spain. J Arid Environ 75(12): 1282-1291. https://doi.org/10.1016/j.jaridenv.2010.12.008

Maltsev YI, Maltseva IA, Solonenko AN, Bren AG (2017) Use of soil biota in the assessment of the ecological potential of urban soils. Biosyst Diversity 25(4): 257-262. https://doi.org/10.15421/011739

Mansour HA, Shaaban AS (2010) Algae of soil surface layer of Wadi Al-Hitan protective area (world heritage site), El-Fayum Depression, Egypt. Am J Sci 6(8):243-255

McKinney ML (2006) Urbanization as a major cause of biotic homogenization. Biol Conserv 127(3):247-260. https://doi.org/10.1016/j.biocon.2005.09.005

Mehta SK, Gaur JP (2005) Use of algae for removing heavy metal ions from wastewater: progress and prospects. Crit Rev Biotechnol 25(3):113-152. https://doi.org/10.1080/07388550500248571

Minaoui F, Hakkoum Z, Douma M, Mouhri K, Loudiki M (2021) Diatom communities as bioindicators of human disturbances on suburban soil quality in arid Marrakesh Area (Morocco). Water Air Soil Pollut 232:146. https://doi.org/10.1007/s11270-021-05094-3

Minz D, Karyo R, Gerstl Z (2011) Effects of treated municipal wastewater irrigation on soil microbiology. In: Levy et al (eds) Treated Wastewater in Agriculture: Use and Impacts on the Environment. Wiley, Hoboken, pp 354-381

Mohan A, Kumar B (2019) Cyanobacterial diversity in agriculturally fertile soil of patna and their population density. Biotechnol Appl Biochem 5(1):15.32. https://doi.org/10.9790/264X-0501011532

Mostafa Fl, Helling CS (2002) Impact of four pesticides on the growth and metabolic activities of two photosynthetic algae. J Environ Sci Health Part B 37(5):417-444. https://doi.org/10.1081/PFC-120014873

Muñoz-Martín MÁ, Becerra-Absalón I, Perona E, Fernández-Valbuena L, GarciaPichel F, Mateo P (2019) Cyanobacterial biocrust diversity in Mediterranean ecosystems along a latitudinal and climatic gradient. New Phytol 221(1):123141. https://doi.org/10.1111/nph.15355

NF ISO 10260 (1992) Water Quality, Measurement of Biochemical Parameters: Spectrometric Determination of the Chlorophyll-a Concentration. Zurich: Beruth Verlag GmbH Berlin

Olsen SR, Cole CV, Watanabe FS, Dean LA (1954) Estimation of available phosphorus in soils by extraction with sodium bicarbonate. Washington, D.C. US Department of Agriculture. Circular No. 939

Patzelt DJ, Hodač L, Friedl T, Pietrasiak N, Johansen JR (2014) Biodiversity of soil cyanobacteria in the hyper-arid Atacama Desert, Chile. J Phycol 50(4):698710. https://doi.org/10.1111/jpy.12196

Prasanna R, Chaudhary V, Gupta V, Babu S, Kumar A, Singh R, Shivay YS, Nain L (2013) Cyanobacteria mediated plant growth promotion and bioprotection against Fusarium wilt in tomato. Eur J Plant Pathol. 136(2):337-353. https:// doi.org/10.1007/s10658-013-0167-x

Rahman MA, Soumya KK, Tripathi A, Sundaram S, Singh S, Gupta A (2011) Evaluation and sensitivity of cyanobacteria, Nostoc muscorum and Synechococcus PCC 7942 for heavy metals stress-a step toward biosensor. Toxicol Environ Chem 93(10):1982-1990. https://doi.org/10.1080/02772248.2 011.606110

Rai PK, Rai A, Sharma NK, Singh S (2018) Study of soil cyanobacteria along a ruralurban gradient. Algal Res 35:142-151. https:/doi.org/10.1016/j.algal.2018.08.032

Subashchandrabose S.R, Ramakrishnan B, Megharaj M, Venkateswarlu K and Naidu R (2013) Mixotrophic cyanobacteria and microalgae as distinctive biological agents for organic pollutant degradation. Environ Int 51:59-72

Rego A, Raio F, Martins TP, Ribeiro H, Sousa AG, Séneca J, Magalhães C (2019) Actinobacteria and cyanobacteria diversity in terrestrial antarctic microenvironments evaluated by culture-dependent and independent methods. Front Microbiol 10:1018. https://doi.org/10.3389/fmicb.2019.01018

Řeháková K, Chlumská Z, Doležal J (2011) Soil cyanobacterial and microalgal diversity in dry mountains of Ladakh, NW Himalaya, as related to site, altitude, and vegetation. Microb Ecol 62(2):337-346. https://doi.org/10.1007/ s00248-011-9878-8

Rejmánková E, Komárek J, Komárková J (2004) Cyanobacteria—a neglected component of biodiversity: patterns of species diversity in inland marshes of northern Belize (Central America). Divers Distrib 10(3):189-199. https://doi. org/10.1111/j.1366-9516.2004.00077.x

Rindi F (2007) Diversity, distribution and ecology of green algae and cyanobacteria in urban habitats. In: Algae and cyanobacteria in extreme environments. Springer, Dordrecht, pp 619-638

Rindi F, Guiry MD (2019) Composition and spatial variability of terrestrial algal assemblages occurring at the bases of urban walls in Europe. Phycologia 43(3):225-235

Rivera-Aguilar V, Montejano G, Rodríguez-Zaragoza S, Durán-Díaz A (2006) Distribution and composition of cyanobacteria, mosses and lichens of the biological soil crusts of the Tehuacán Valley, Puebla, México. J Arid Environ 67(2):208-225. https://doi.org/10.1016/j.jaridenv.2006.02.013

Rocha F, Lucas-Borja ME, Pereira P, Muñoz-Rojas M (2020) Cyanobacteria as a nature-based biotechnological tool for restoring salt-affected soils. Agronomy 10(9):1321. https://doi.org/10.3390/agronomy10091321

Rodríguez AA, Stella AM, Storni MM, Zulpa G, Zaccaro MC (2006) Effects of cyanobacterial extracellular products and gibberellic acid on salinity tolerance in Oryza sativa L. Saline Syst 2(1):7. https://doi.org/10.1186/1746-1448-2-7

Rossi F, De Philippis R (2015) Role of cyanobacterial exopolysaccharides in phototrophic biofilms and in complex microbial mats. Life 5(2):1218-1238. https://doi.org/10.3390/life5021218

Rossi F, Li H, Liu Y, De Philippis R (2017) Cyanobacterial inoculation (cyanobacterisation): perspectives for the development of a standardized 
multifunctional technology for soil fertilization and desertification reversal. Earth-Sci Rev 171:28-43. https://doi.org/10.1016/..earscirev.2017.05.006

Rutgers M, Jeroen P, van Leeuwen JP, Vrebos D, van Wijnen HJ, Schouten T, de Goede RGM (2019) Mapping Soil Biodiversity in Europe and Netherlands. Soil Syst 3:39. https://doi.org/10.3390/soilsystems3020039

Schwartz C, Séré G, Stas M, Blanchart A, Morel JL, Consales JN (2015) Quelle ressource sol dans les villes pour quels services et quels aménagements? Innov Agron 45:1-11

Shanab S, Essa A, Shalaby E (2012) Bioremoval capacity of three heavy metals by some microalgae species (Egyptian isolates). Plant Signal Behav 7(3):392-399. https://doi.org/10.4161/psb.19173

Shanab SM (2006) Algal flora of ain helwan i. algae of the worm spring. Egypt. J Phycol 7(2):209-231

Shariatmadari Z, Riahi H, Seyed Hashtroudi M, Ghassempour A, Aghashariatmadary Z (2013) Plant growth promoting cyanobacteria and their distribution in terrestrial habitats of Iran. J Soil Sci Plant Nutr 59(4):535-547. https://doi.org/10.1080/00380768.2013.782253

Sharma NK (2015) From natural to human-impacted ecosystems: rationale to investigate the impact of urbanization on cyanobacterial diversity in soils, Biodivers Conserv 24(4):1007-1015. https://doi.org/10.1007/s10531-015-0897-5

Shekhovtseva OG (2014) Soil algae in urban ecosystems of the city of Mariupol. Fundamental Appl Soil Sci 15(1-2):63-69. https://doi.org/10.15421/041406

Shekhovtseva OG, Mal'tseva IA (2015) Physical, chemical, and biological properties of soils in the city of Mariupol, Ukraine. Eurasian J Soil Sci 48(12): 1393-1400. https://doi.org/10.1134/S1064229315120145

Singh H, Khattar JS, Ahluwalia AS (2014) Cyanobacteria and agricultural crops. Vegetos 27(1):37-44. https://doi.org/10.5958/j.2229-4473.27.1.008

Singh JS, Kumar A, Rai AN, Singh DP (2016) Cyanobacteria: a precious bioresource in agriculture, ecosystem, and environmental sustainability. Front Microbiol 7:529. https://doi.org/10.3389/fmicb.2016.00529

Skulberg OM (1983) Culture collection of algae at Norwegian Institute for water research. Norwegian Institute for Water Research, Blindern, Oslo

Sommer V, Mikhailyuk T, Glaser K, Karsten U (2020) Uncovering unique green algae and cyanobacteria isolated from biocrusts in highly saline potash tailing pile habitats, using an integrative approach. Microorganisms 8(11): 1667. https://doi.org/10.3390/microorganisms8111667

Song T, Mårtensson L, Eriksson T, Zheng W, Rasmussen U (2005) Biodiversity and seasonal variation of the cyanobacterial assemblage in a rice paddy field in Fujian, China. FEMS Microbiol Ecol 54(1):131-140

Stour L, Agoumi A (2008) Climatic drought in Morocco during the last decades. Hydroécol Appliquée 16:215-232. https://doi.org/10.1051/hydro/2009003

Trzcińska M, Pawlik-Skowrońska B (2008) Soil algal communities inhabiting zinc and lead mine spoils. J Appl Phycol 20(4):341-348. https://doi.org/10.1007/s1 0811-007-9259-3

Venter A, Levanets A, Siebert S, Rajakaruna N (2015) A preliminary survey of the diversity of soil algae and cyanoprokaryotes on mafic and ultramafic substrates in South Africa. Aust J Bot 63(4):341-352. https://doi.org/10.1071/BT14207

Vijayakumar S (2012) Potential applications of cyanobacteria in industrial effluents - a review. J Bioremed Biodeg 3(6):1-6. https://doi.org/10.4172/2155-6199.1000154

Wang W, Wu T, Li Y, Xie S, Han B, Zheng H, Ouyang Z (2020) Urbanization impacts on natural habitat and ecosystem services in the Guangdong-Hong Kong-Macao "Megacity". Sustainability 12(16):6675. https://doi.org/10.3390/ su12166675

Whitton BA, Potts M (2000) Soils and rice-fields. In: The ecology of cyanobacteria. Springer, Dordrecht, pp 233-255

Whitton BA, Potts M (eds) (2007) The ecology of cyanobacteria: their diversity in time and space. Springer Science \& Business Media. https://doi.org/10.1007/ 978-94-007-3855-3_10 Subaerial Cyanobacteria

Zancan S, Trevisan R, Paoletti MG (2006) Soil algae composition under different agro-ecosystems in North-Eastern Italy. Agric Ecosyst Environ 112(1):1-12. https://doi.org/10.1016/j.agee.2005.06.018

Zielinska S, Radkowski P, Blendowska A, Ludwig-Gałezowska A, Łoś JM, Łoś M (2017) The choice of the DNA extraction method may influence the outcome of the soil microbial community structure analysis. Microbiol Open 6(4):e00453. https://doi.org/10.1002/mbo3.453

\section{Publisher's Note}

Springer Nature remains neutral with regard to jurisdictional claims in published maps and institutional affiliations.

\section{Submit your manuscript to a SpringerOpen ${ }^{\circ}$ journal and benefit from:}

- Convenient online submission

- Rigorous peer review

- Open access: articles freely available online

- High visibility within the field

- Retaining the copyright to your article

Submit your next manuscript at $\boldsymbol{\nabla}$ springeropen.com 